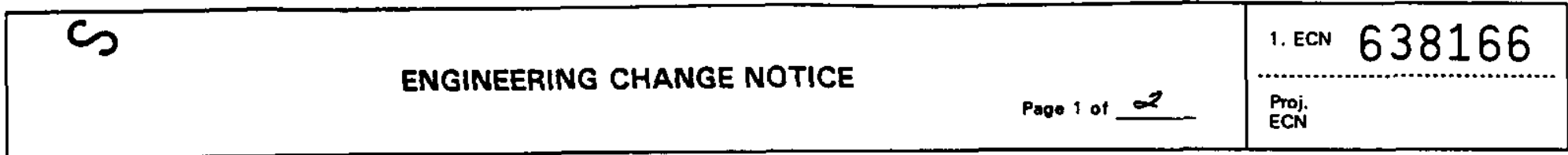

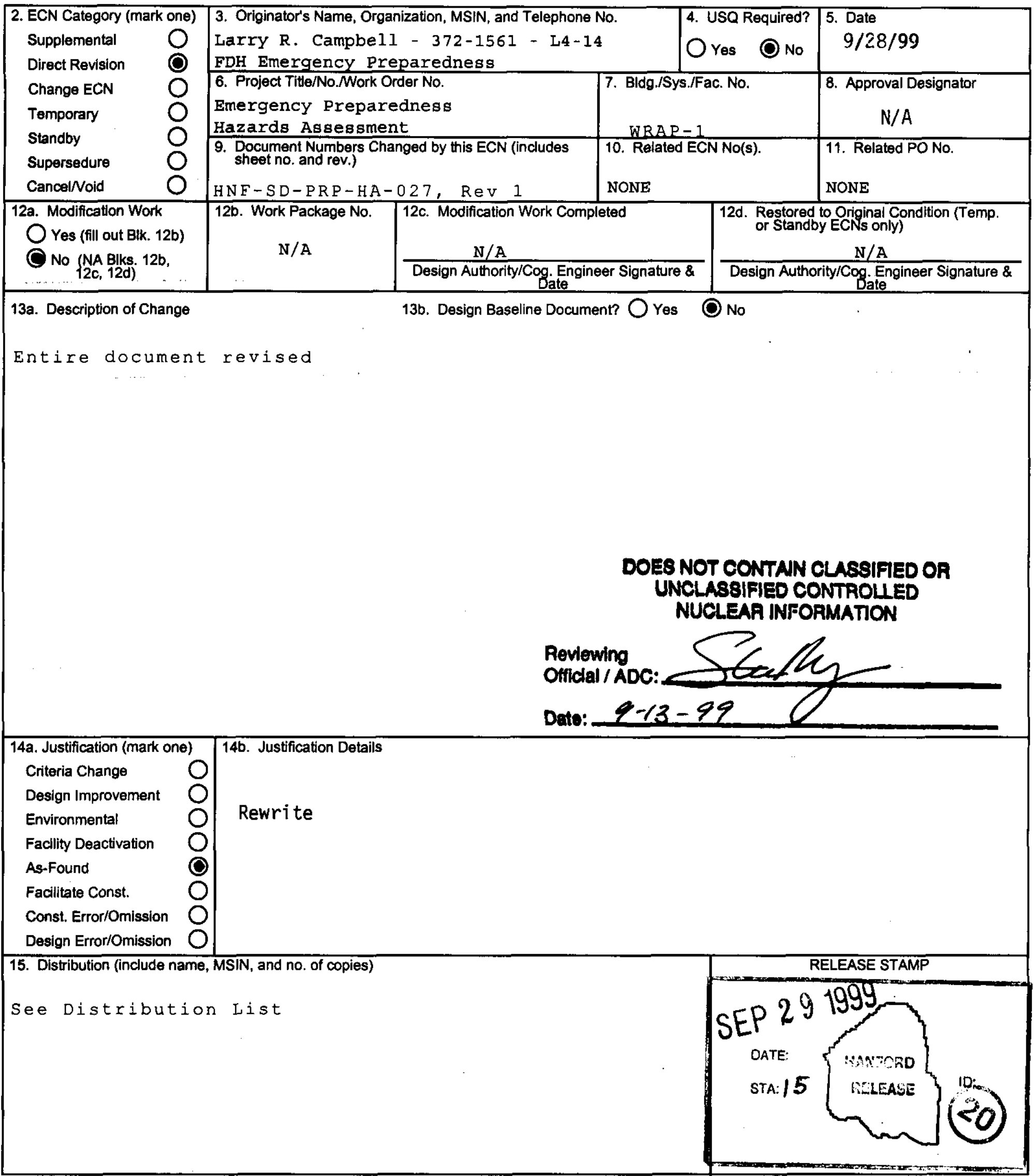


ENGINEERING CHANGE NOTICE

\begin{tabular}{l|l} 
Page 2 of 2 & 2 \\
\hline
\end{tabular}

16. Design Verification Required

\section{Ores \\ ( No}

17. Cost Impact

ENGINEERING

Additional $\bigcirc \$$

Savings $\bigcirc$

\section{NINERING}

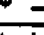

\section{CONSTRUCTION}

$\begin{array}{ll}\text { Additional } & \bigcirc \\ \text { Savings } & \$\end{array}$

18. Schedule Impact (days)

Improvement

Delay

19. Change Impact Review: Indicate the related documents (other than the engineering documents identified on Side 1) that will be affected by the change described in Block 13. Enter the affected document number in Block 20.

\section{SDD/DD}

Functional Design Criteria

Operating Specification

Criticality Specification

Conceptual Design Report

Equipment Spec.

Const. Spec.

Procurement Spec.

Vendor Information

OM Manual

FSAR/SAR

Safety Equipment List

Radiation Work Permit

Environmental Impact Statement

Environmental Report

Environmental Permit $\square$
$\square$
$\square$
$\square$
$\square$
$\square$
$\square$
$\square$
$\square$
$\square$
$\square$
$\square$
$\square$
$\square$
$\square$
$\square$
Seismic/Stress Analysis

Stress/Design Report

Interface Control Drawing

Calibration Procedure

Installation Procedure

Maintenance Procedure

Engineering Procedure

Operating Instruction

Operating Procedure

Operational Safety Requirement IEFD Drawing

Cell Arrangement Drawing

Essential Material Specification

Fac. Proc. Samp. Schedule

Inspection Plan

Inventory Adjustment Request $\square$
$\square$
$\square$
$\square$
$\square$
$\square$
$\square$
$\square$
$\square$
$\square$
$\square$
$\square$
$\square$
$\square$
$\square$
$\square$
Tank Calibration Manual Health Physics Procedure Spares Multiple Unit Listing Test Procedures/Specification Component Index

ASME Coded Item Human Factor Consideration Computer Software Electric Circuit Schedule ICRS Procedure Process Control Manual/Plan Process Flow Chart

Purchase Requisition

Tickler File

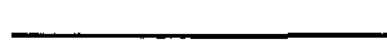

20. Other Affected Documents: (NOTE: Documents listed below will not be revised by this ECN.) Signatures below indicate that the signing organization has been notified of other affected documents listed below.

Document Number/Revision

Document Number/Revision

Document Number/Revision

NONE

21. Approvals

\section{Signature}

Design Authority

Cog. Eng. LR Campbell AC

QA

Safety

Environ.

Other

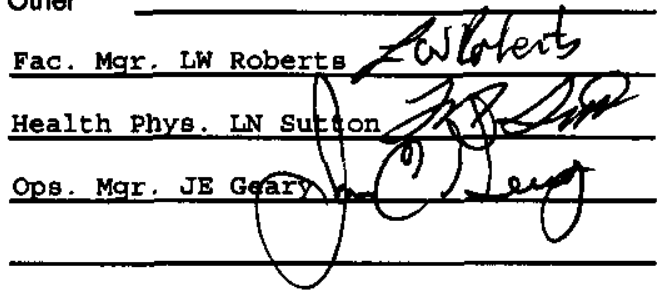

Date

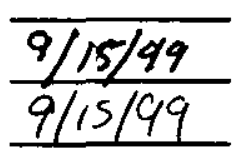

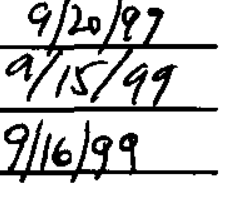

Signature

Date
Design Agent

PE

QA

Safety

Design

Environ.

Other

\section{DEPARTMENT OF ENERGY}

Signature or a Control Number that tracks the Approval Signature

ADDITIONAL 


\section{DISTRIBUTION SHEET}

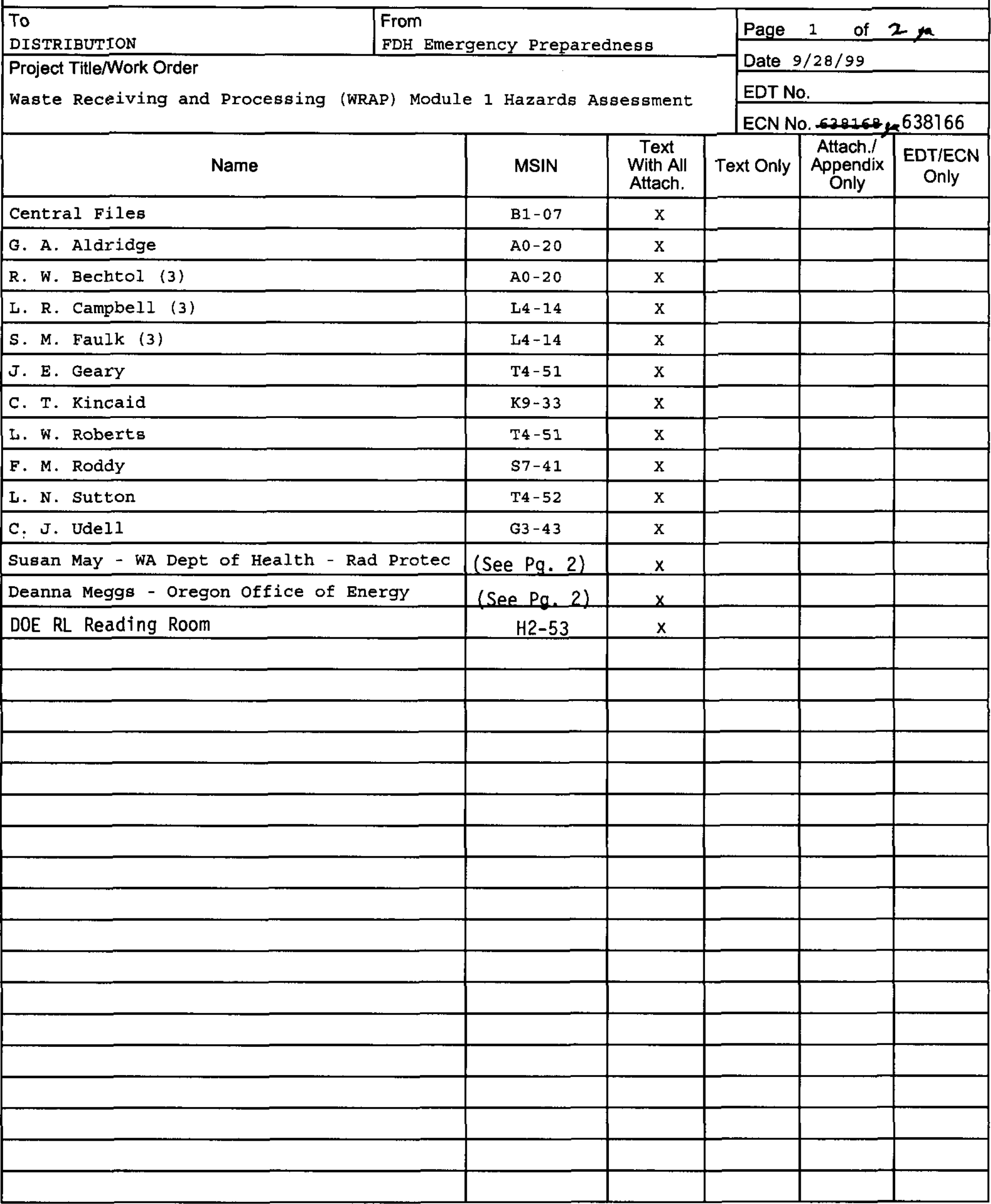




\title{
WASTE RECEIVING AND PROCESSING (WRAP) MODULE 1 HAZARDS ASSESSMENT
}

\author{
Larry R. Campbell \\ Fluor Daniel Hanford, Inc. \\ Richland, WA 99352 \\ U.S. Department of Energy Contract DE-AC06-96RL13200
}

EDT/ECN: $\quad 638166$

Org Code: 4 H330

B\&R Code: YN0100000
UC: 506

Charge Code: 103049/CB60 HN9F1391

Total Pages: 62

Key Words: Waste Receiving and Processing Module 1, Hazards Assessment, Emergency Planning and Preparedness

Abstract: This document establishes the technical basis in support of Emergency Planning activities for the WRAP Module 1 Facility on the Hanford Site. Through this document, the technical basis for the development of facility specific Emergency Action Levels and Emergency Planning Zone is demonstrated.

TRADEMARK DISCLAIMER. Reference herein to any specific commercial product, process, or service by trade nume, trademark, manufacturer, or otherwise, does not necessarily constitute or imply its endorsement, recommendation, or favoring by the United States Goverment or any agency thereof or its contractors or subcontractors.

Printed in the United states of America. To obtain copies of this document, contact: WHC/BCS Document Control Services, P.0. Box 1970, Mailstop H6-08, Richtand WA 99352, Phone (509) 372-2420; Fax (509) 376-4989.
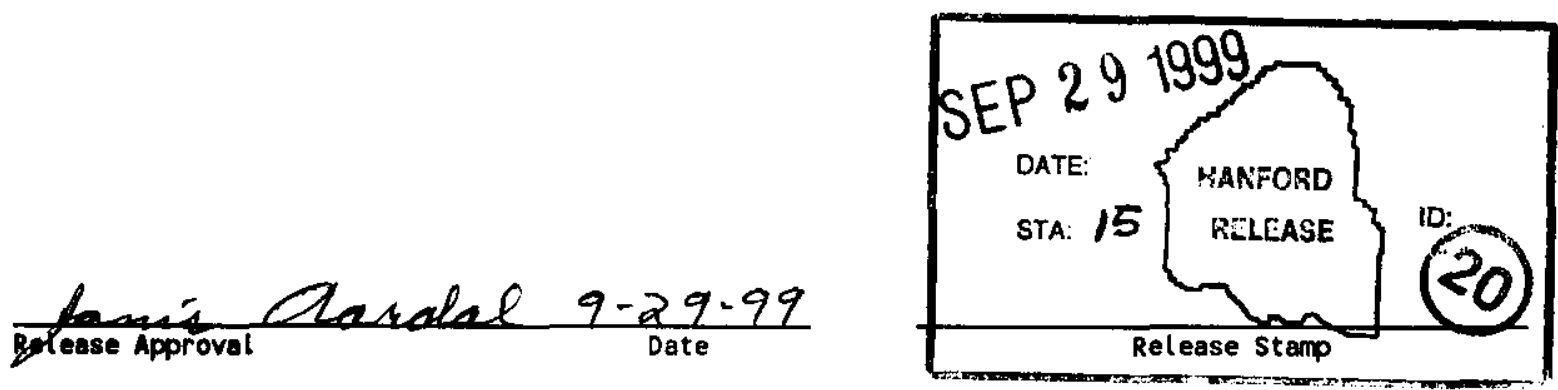

Approved for Public Release 


\section{RECORD OF REVISION}

(2) Title

WASTE RECEIVING AND PROCESSING (WRAP) MODULE 1 HAZARDS ASSESSMENT

Change Control Record

(3) Revision

(4) Description of Change - Replace, Add, and Delete Pages

(7)

\begin{tabular}{l|ll}
0 & EDT 608164
\end{tabular}

$1 \quad$ Complete Revixion - ECN 638127

2
Authorized for Release

\begin{tabular}{l|l} 
(5) Cog. Engr. & (6) Cog. Mgr. Date
\end{tabular}

LN sutton

RH Palmer5/16/96

LN Sutton SM Faulk 6/11/97 LB Campbeyl Sy Faulk

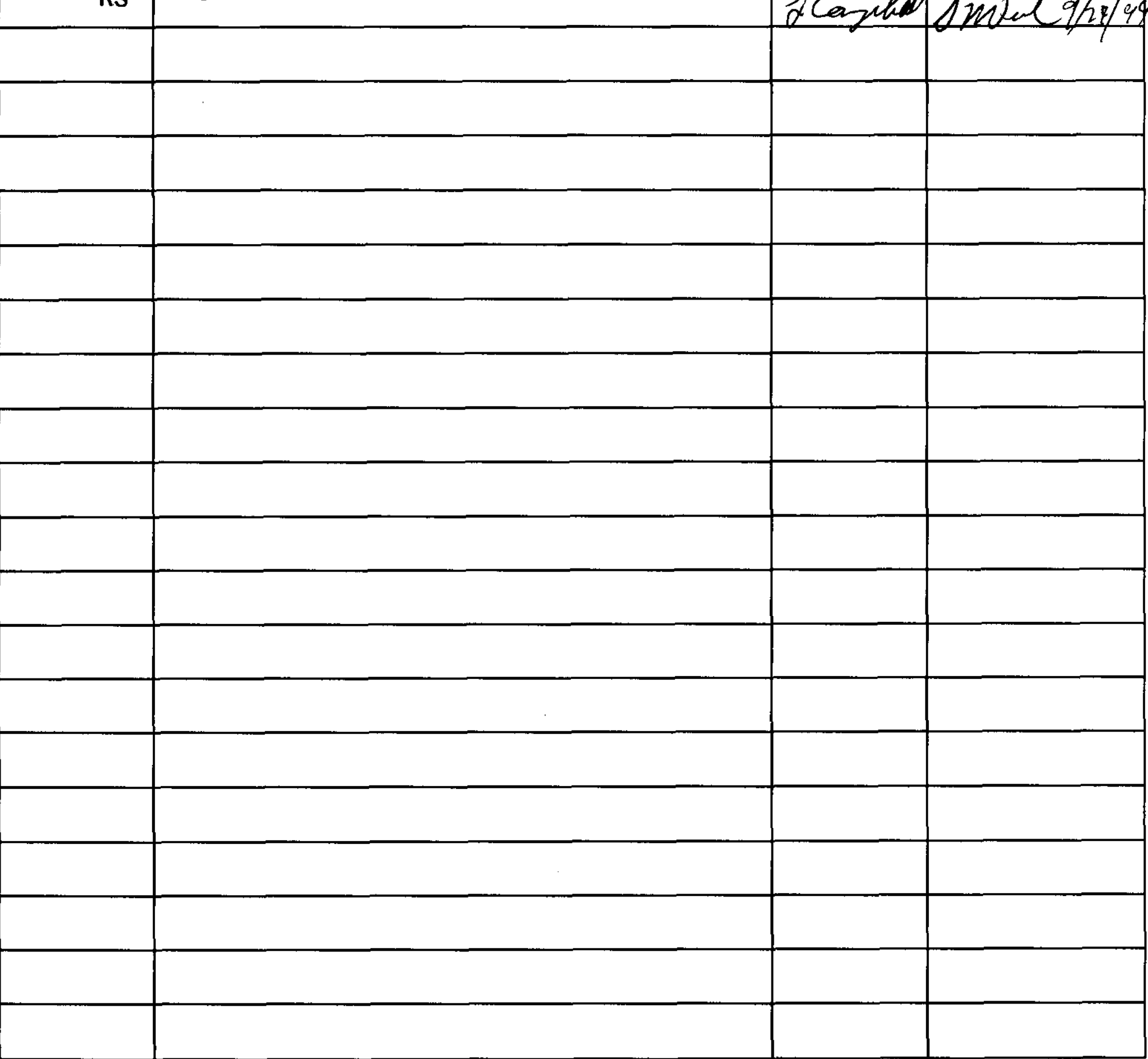


HNF-SD-PRP-HA-027, Rev. 2

\section{WASTE RECEIVING AND PROCESSING}

\section{HAZARDS ASSESSMENT}

Gregory F. Martin 


\section{TABLE OF CONTENTS}

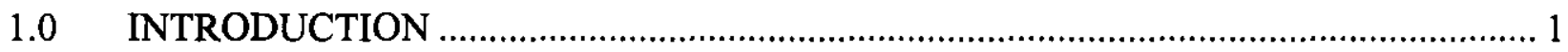

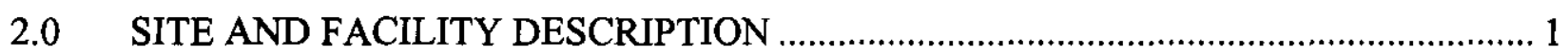

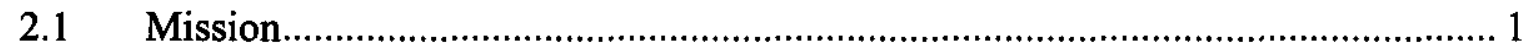

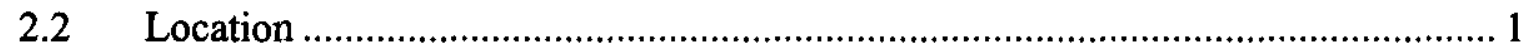

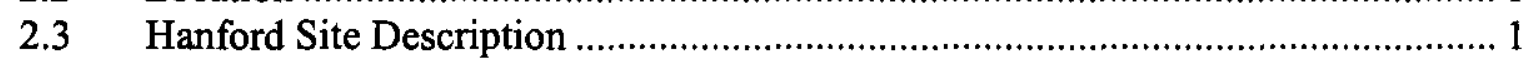

2.3.1 Physical Description ............................................................................ 1

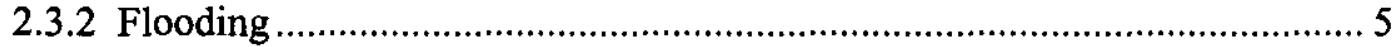

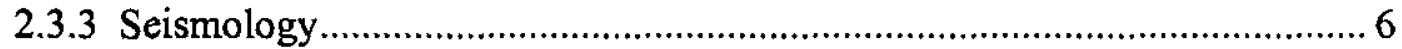

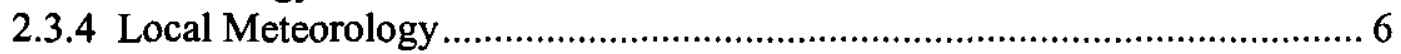

2.3.5 Wind and Tornado ............................................................................... 7

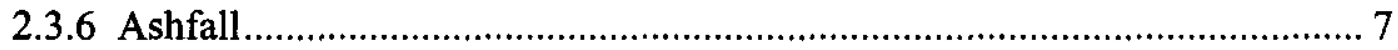

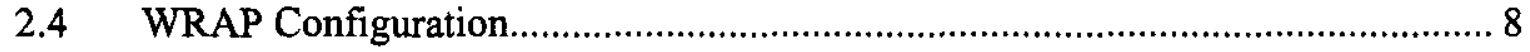

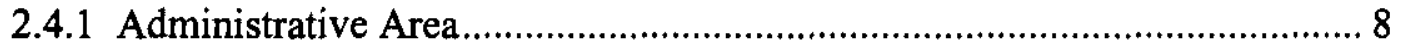

2.4.2 Personnel Support Area ........................................................................ 8

2.4.3 Shipping and Receiving Area ............................................................... 10

2.4.4 Nondestructive Examination/Nondestructive Assay Area........................... 10

2.4.5 Waste Process Area................................................................................. 10

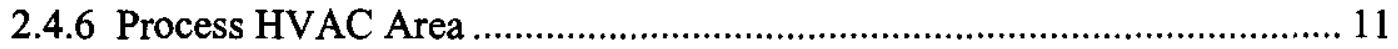

2.4.7 Control and Computer Area .................................................................. 11

2.5 WRAP Basic Process Description ................................................................ 11

3.0 IDENTIFICATION AND SCREENING OF HAZARDS .......................................... 13

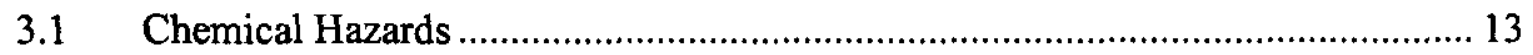

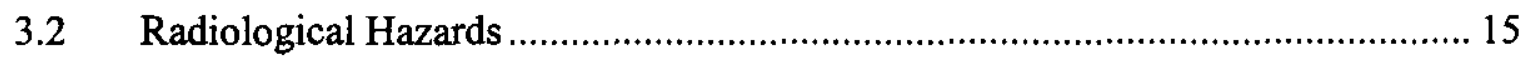

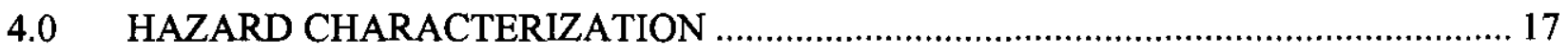

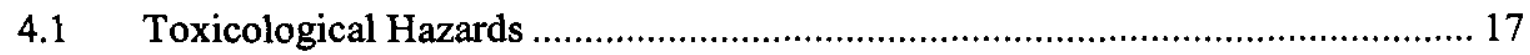

4.2 Radiological Hazards ………........................................................................ 17

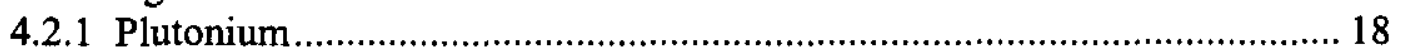

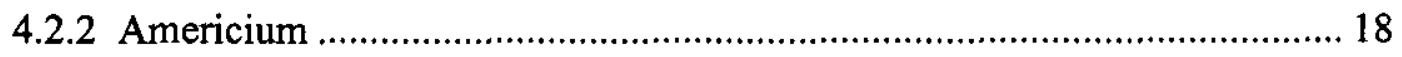

4.2.3 Strontium and Cesium .......................................................................... 19

4.3 Radioactive Material Confinement ................................................................ 19

5.0 CONSEQUENCE MODELS, RECEPTOR LOCATIONS AND CLASSIFICATION

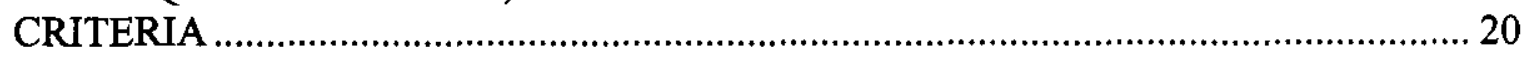

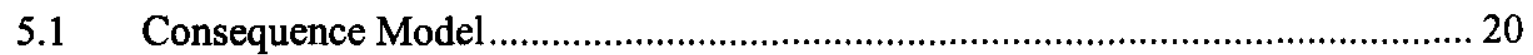

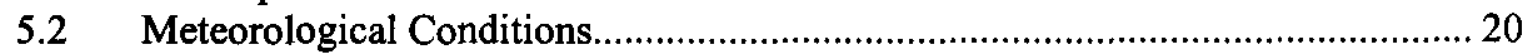

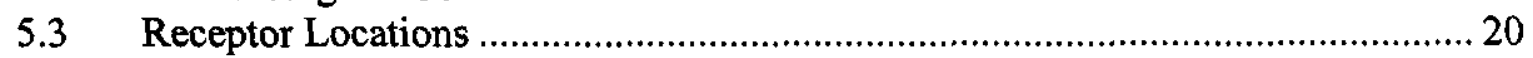

$5.4 \quad$ Emergency Classification Criteria …………................................................... 21

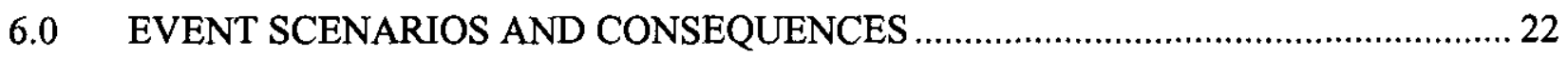

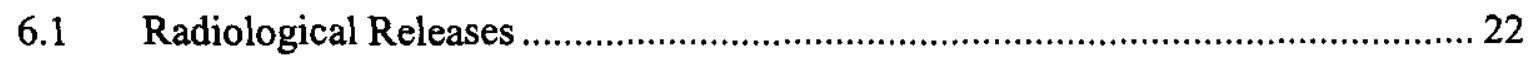

6.1.1 NDE/NDA or Shipping and Receiving Area Spill .................................... 24 


\section{HNF-SD-PRP-HA-027, Rev. 2}

6.1.2 NDE/NDA or Shipping and Receiving Area Drum Spill w/Fire................ 26

6.1.3 NDE/NDA or Shipping and Receiving Area Drum Explosion................... 28

6.1.4 Fire in Process Enclosures w/Filter Failure ............................................... 31

6.1.5 Drum Fire in TRU Process Enclosure w/Filter Intact................................. 33

6.1.6 Drum Explosion in Process Enclosure w/Filter Failure............................... 33

6.1.7 Drum Explosion in Process Enclosure w/Filter Intact ................................. 35

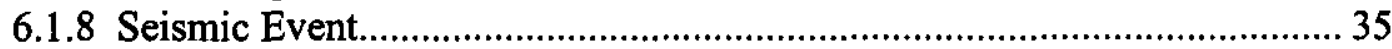

6.1.9 Beyond Design Basis Seismic Event ......................................................... 37

6.1.10 Sabotage Event..................................................................................... 39

7.0 SUGGESTED EMERGENCY ACTION LEVELS AND EVENT CLASSIFICATIONS

.

7.1 Toxic Chemical Emergencies ....................................................................... 41

7.2 Radiological Emergencies ............................................................................. 41

7.2.1 Loss of Confinement........................................................................... 42

7.2.2 Facility Fire ........................................................................................ 43

7.2.3 Explosion of Waste Container ................................................................... 44

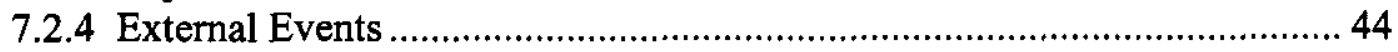

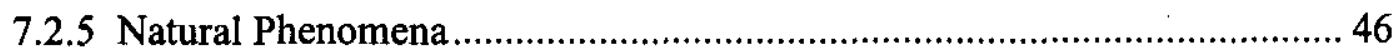

7.2.6 Safeguards and Security......................................................................... 48

7.2.7 Event Classification Based on Radiological Field Measurements .............. 50

8.0 THE EMERGENCY PLANNING ZONE ...............................................................5

9.0 MAINTENANCE AND REVIEW OF THIS HAZARDS ASSESSMENT ..................... 55

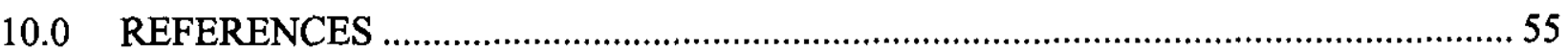

\section{LIST OF FIGURES}

Figure 2.1 Location of the Hanford Site .............................................................................. 3

Figure 2.2 The 200 West Area ......................................................................................... 4

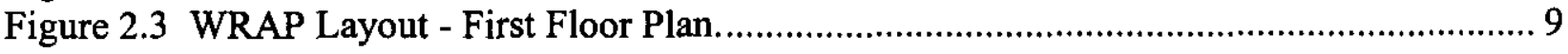

\section{LIST OF TABLES}

Table 2.1 Estimated Ash Depth at Hanford from Major Eruptions .............................................. 8

Table 3.1 Hazardous Material Components........................................................................ 14

Table 4.1 TRU 12\% (Nominal) ${ }^{240} \mathrm{Pu}$, 20-yr Aged .............................................................. 18

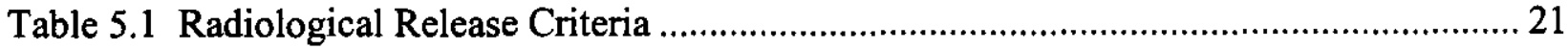

Table 5.2 Non-Radiological Release Criteria ………….......................................................... 21

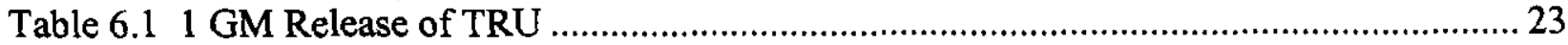

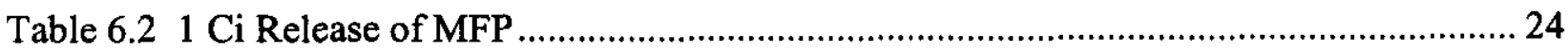

Table 6.3 TRU Drum Spill TEDEs.................................................................................. 24

Table 6.4 TRU Drum Spill PAG Distance............................................................................ 25 


\section{HNF-SD-PRP-HA-027, Rev. 2}

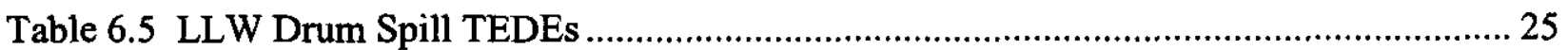

Table 6.6 LLW Drum Spill PAG Distances ....................................................................... 25

Table 6.7 TRU SWB Spill TEDEs ……………………................................................ 26

Table 6.8 TRU SWB Spill PAG Distances..................................................................... 26

Table 6.9 NDE/NDA Shipping and Receiving Area Spill w/Fire TEDEs................................. 27

Table 6.10 NDE/NDA Shipping and Receiving Area Drum Spill w/Fire PAG Distances ......... 27

Table 6.11 LLW Drum Fire TEDEs ................................................................................. 27

Table 6.12 LLW Drum Fire PAG Distances........................................................................ 28

Table 6.13 TRU Drum Explosion TEDEs .......................................................................2 28

Table 6.14 TRU Drum Explosion PAG Distances ................................................................. 29

Table 6.15 LLW Drum Explosion TEDEs .............................................................................. 29

Table 6.16 LLW Drum Explosion PAG Distances.................................................................. 29

Table 6.17 TRU Drum Explosion and Fire TEDEs................................................................ 30

Table 6.18 TRU Drum Explosion and Fire PAG Distances ...................................................... 30

Table 6.19 LLW Drum Explosion and Fire TEDEs ..................................................................... 31

Table 6.20 LLW Drum Explosion and Fire PAG Distances......................................................... 31

Table 6.21 TRU Process Enclosure Fire TEDEs ...................................................................... 32

Table 6.22 TRU Process Enclosure Fire PAG Distances ........................................................... 32

Table 6.23 LLW Process Enclosure Fire TEDEs ……………................................................ 32

Table 6.24 LLW Process Enclosure Fire PAG Distances.......................................................... 33

Table 6.25 TRU Process Enclosure Explosion TEDEs …………………………………......... 34

Table 6.26 TRU Process Enclosure Explosion PAG Distances.................................................... 34

Table 6.27 LLW Process Enclosure Explosion TEDEs............................................................... 34

Table 6.28 LLW Process Enclosure Explosion PAG Distances.................................................. 35

Table 6.29 Seismic Event TRU Release TEDEs ………….................................................... 36

Table 6.30 Seismic Event TRU Release PAG Distances............................................................. 36

Table 6.31 Seismic Event LLW Release TEDEs................................................................... 37

Table 6.32 Seismic Event LLW Release PAG Distances ............................................................ 37

Table 6.33 Beyond Design Basis Seismic TRU TEDEs........................................................... 38

Table 6.34 Beyond Design Basis Seismic TRU PAG Distances................................................ 38

Table 6.35 Beyond Design Basis Seismic LLW TEDEs ........................................................... 39

Table 6.36 Beyond Design Basis Seismic LLW PAG Distances ................................................. 39

Table 6.37 Sabotage Event TRU TEDEs................................................................................40

Table 6.38 Sabotage Event TRU PAG Distances ................................................................... 40

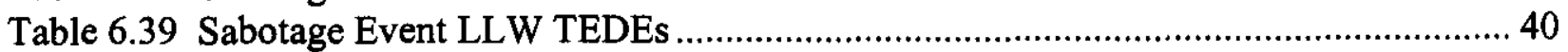

Table 6.40 Sabotage Event LLW PAG Distances ...................................................................... 41

Table 7.1 Release Quantities that Meet Classification Criteria ................................................... 50

Table 8.1 Dose at EPZ Boundary ……………………..................................................... 54 


\section{HNF-SD-PRP-HA-027, Rev. 2}

\subsection{INTRODUCTION}

This report documents the hazards assessment for the Waste Receiving and Processing Facility (WRAP) located on the U.S. Department of Energy (DOE) Hanford Site. The Project Hanford Management Contractor, Fluor Daniel Hanford, Inc., has assigned responsibility for safe operation of WRAP to Waste Management Federal Services of Hanford, Inc. This hazards assessment was conducted to provide the emergency planning technical basis for the WRAP. DOE Orders require an emergency planning hazards assessment for each facility that has the potential to reach or exceed the lowest level emergency classification.

\subsection{SITE AND FACILITY DESCRIPTION}

\section{$2.1 \quad$ Mission}

WRAP is designed to receive, confirm, repackage, certify, treat, store, and ship contacthandled $(\mathrm{CH})$ transuranic (TRU) waste and low-level waste (LLW) from past and present DOE activities. WRAP is designed to provide safer, more efficient methods of handling the waste than currently exist on the Hanford Site and contributes to the achievement of as-low-as reasonably achievable (ALARA) goals for Hanford Site Waste Management. The main objective of WRAP is to examine, assay, process, repackage (if necessary) and certify the waste described above for shipment to a treatment, storage or disposal facility. More detailed facility and process descriptions can be found in the WRAP Final Safety Analysis Report (WMH, 1998).

\section{$2.2 \quad$ Location}

WRAP is located in the northwest part of the 200 West Area of the DOE Hanford Site. The nearest site boundary is about 11.7 kilometers ( 7.2 miles) to the west. For purposes of emergency planning, the nearest shore of the Columbia River is treated as site boundary when it is closer than the actual site boundary. The nearest shore of the Columbia River is about 8.7 kilometers ( 5.4 miles) to the north. This distance will be used in evaluating offsite consequences. The 200 West Area is located on a plateau at an elevation ranging from approximately 190 to 245 meters ( 620 to 800 feet) above mean sea level near the middle of the Hanford Site (see figures 2.1 and 2.2).

\subsection{Hanford Site Description}

\subsubsection{Physical Description}

The DOE Hanford Site lies within the semiarid Pasco Basin of the Columbia Plateau in southeastern Washington State (figure 2.1). The Hanford Site occupies an area of about $1450 \mathrm{~km}^{2}\left(\sim 560 \mathrm{mi}^{2}\right)$ north of the confluence of the Snake and Yakima Rivers with the Columbia River. The Hanford Site is about $50 \mathrm{~km}(30 \mathrm{mi})$ north to south and $40 \mathrm{~km}(24 \mathrm{mi})$ east to west. This land, with restricted public access, provides a buffer for the smaller areas currently used for research, waste storage, and waste disposal; only about $6 \%$ of the land area has been disturbed 
and is actively used. The Columbia River flows through the northern part of the Hanford Site, and turning south, it forms part of the Site's eastern boundary. The Yakima River runs along part of the southern boundary and joins the Columbia River south of the city of Richland, which bounds the Hanford Site on the southeast. Rattlesnake Mountain, the Yakima Ridge, and the Umtanum Ridge form the southwestern and western boundary. The Saddle Mountains form the northern boundary of the Hanford Site. There are plans to reduce the size of the Hanford Reservation. The new boundary will likely be the Columbia River on the north and east and Highway 240 on the west and south.

Major metropolitan areas within the broad vicinity of Hanford include Spokane, Washington, about 120 air miles to the northeast; Seattle, Washington, about 130 air miles to the northwest; and Portland, Oregon, about 150 air miles to the southwest. Two other areas of significant population density in Washington State include Moses Lake, about 30 miles north of the K-Area and the Yakima Valley, extending from Yakima, about 45 miles west of the Hanford Site, to the Tri-Cities (Pasco, Kennewick and Richland). The nearest of the Tri-Cities, Richland, is immediately south of the Site. 
HNF-SD-PRP-HA-027, Rev. 2

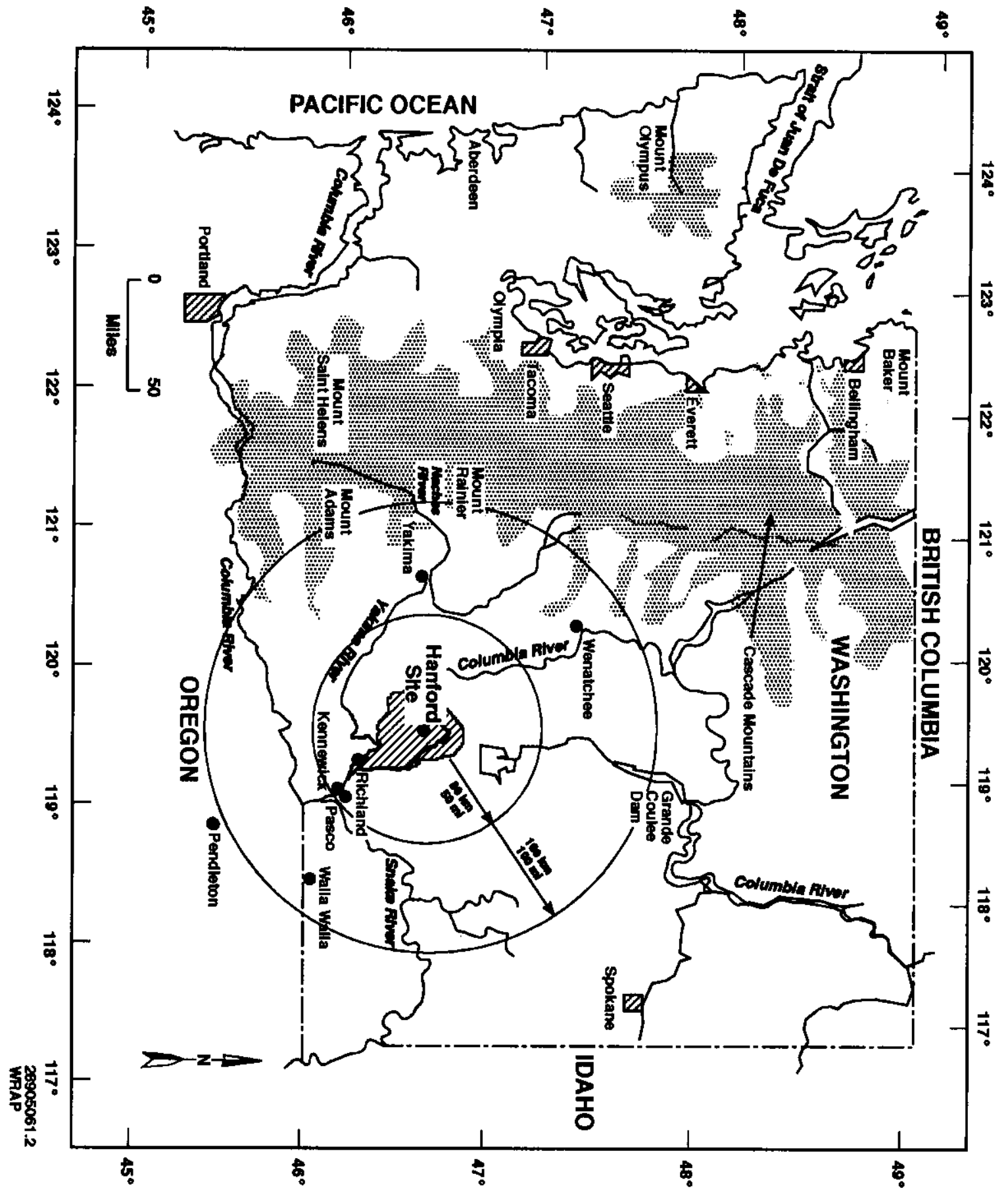

Figure 2.1 Location of the Hanford Site (Source: WHC-SD-W112-RPT-001). 


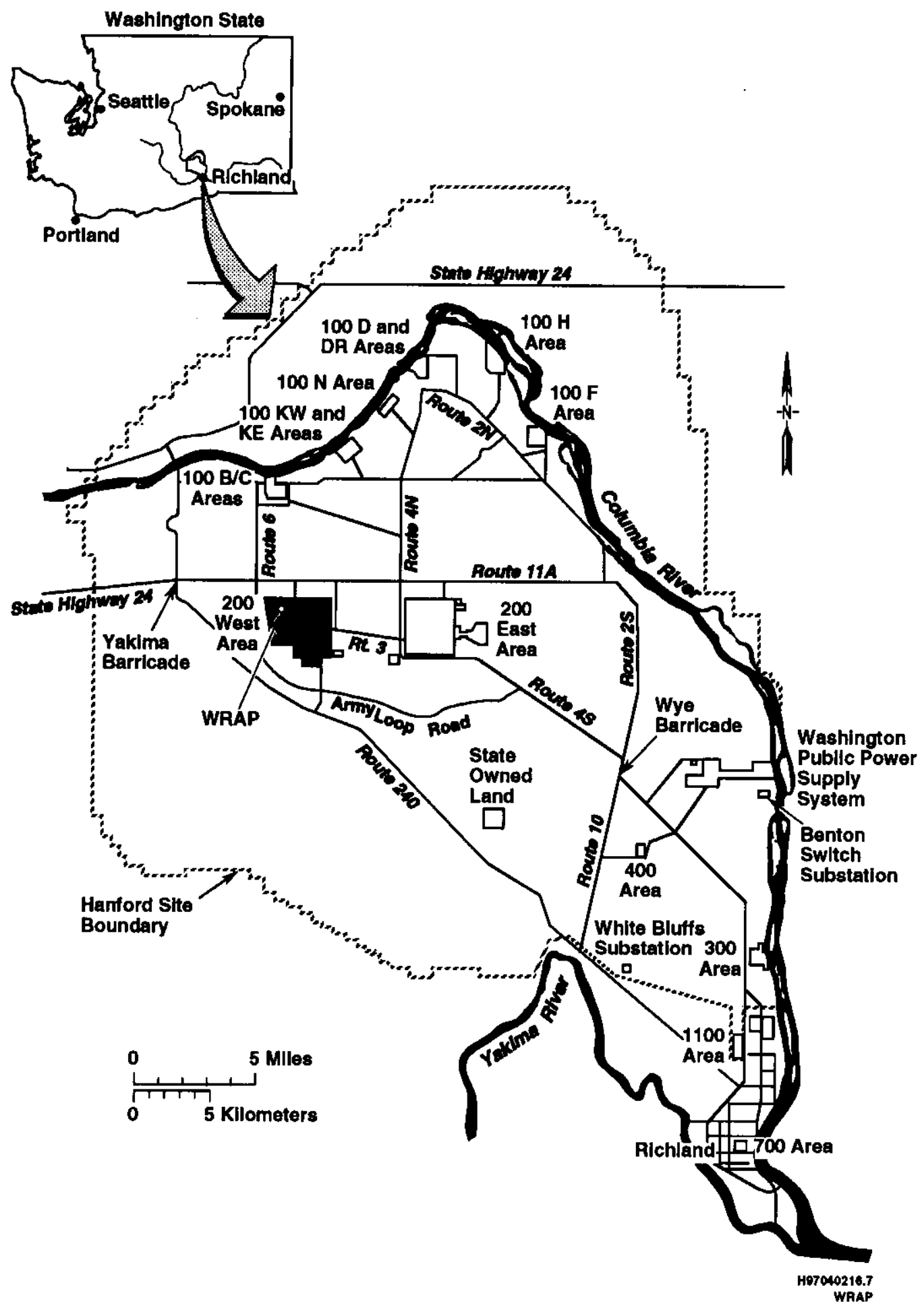

Figure 2.2 The 200 West Area (Source: WHC-SD-W112-RPT-001). 


\section{HNF-SD-PRP-HA-027, Rev. 2}

The Hanford Reservation contains the following major facilities or activities: six reactor areas designated 100-B/C, 100-N, 100-KE/KW, 100-D/DR, 100-H, and 100-F, which contain eight shutdown production reactors and one shutdown dual purpose reactor ( $\mathrm{N}$ Reactor); the $\mathrm{KE}$ and KW Fuel Storage Facilities within the $100-\mathrm{KE} / \mathrm{KW}$ Area; two areas for waste processing and waste storage designated 200-E and 200-W Areas; the 300 Area which contains a shutdown fuel fabrication facility and laboratory facilities supporting all of DOE's Hanford Programs; the 400 Area which contains the shutdown Fast Flux Test Facility (FFTF); a commercial nuclear waste burial operation on land leased to the State of Washington; and an operating Energy Northwest (formerly Washington Public Power Supply System) nuclear power plant.

\subsubsection{Flooding}

Large Columbia River floods have occurred in the past (DOE 1987), but the likelihood of recurrence of large-scale flooding has been reduced by the construction of several flood control/water storage dams upstream of the Site.

There are no Federal Emergency Management Agency (FEMA) flood plain maps for the Hanford Reach of the Columbia River. FEMA only maps developing areas, and the Hanford Reach is specifically excluded.

Evaluation of flood potential is conducted in part through the concept of the probable maximum flood (PMF), which is determined from the upper limit of precipitation falling on a drainage area and other hydrologic factors, such as antecedent moisture conditions, snowmelt, and tributary conditions, that could result in maximum runoff. The probable maximum flood for the Columbia River below Priest Rapids Dam has been calculated to be $40,000 \mathrm{cms}$ ( 1.4 million cfs) and is greater than the 500-year flood. The PMF is not expected to inundate the buildings in 300 Area but would flood the $100 \mathrm{~F}, 100 \mathrm{H}$, and part of the $100 \mathrm{~B} / \mathrm{C}$ Areas. The main export water river pumps that supply water to the 100 (K Fuel Basins) and 200 Areas will also be submerged and likely damaged. The PMF may also flood access roads and temporarily cut off electrical power to the 100 and 300 Areas (see figure 4.2-10 in Cushing 1992).

Potential dam failures on the Columbia River have been evaluated. Upstream failures could arise from a number of causes, with the magnitude of the resulting flood depending on the degree of breaching at the particular dam. The U.S. Army Corps of Engineers evaluated a number of scenarios on the effects of failures of Grand Coulee Dam, assuming flow conditions of the order of $11,000 \mathrm{cms}(400,000 \mathrm{cfs})$. For purposes of emergency planning, they hypothesized that $25 \%$ and $50 \%$ breaches, the "instantaneous" disappearance of $25 \%$ or $50 \%$ of the center section of the dam, would result from the detonation of nuclear explosives in sabotage or war. The discharge or floodwave resulting from such an instantaneous $50 \%$ breach at the outfall of the Grand Coulee Dam was determined to be $600,000 \mathrm{cms}$ ( 21 million cfs). In addition to the areas inundated by the probable maximum flood (see figure 4.2-10 in Cushing 1992), the remainder of the 100 Areas, the 300 Area, and nearly all of Richland, Washington, would be flooded (DOE 1986 and ERDA 1976). Flooding of this magnitude would be a regional emergency along the entire downstream length of the Columbia River. Columbia River flooding is considered in a separate hazard assessment for the entire Hanford Site (Campbell, 1996). 


\section{HNF-SD-PRP-HA-027, Rev. 2}

There have been fewer than 20 major floods on the Yakima River since 1862 (DOE 1986). The most severe occurred in November 1906, December 1933, May 1948, and March 1996. The recurrence intervals for the 1933 and 1948 floods are estimated at 170 and 33 years, respectively. The development of irrigation reservoirs within the Yakima River Basin has considerably reduced the flood potential of the river.

\subsubsection{Seismology}

The Hanford Reservation is in a region of low to moderate seismicity. The historic record of earthquakes in the Pacific Northwest dates from about 1840. The early part of this record is based on newspaper reports of structural damage and human perception of the shaking, as classified by the Modified Mercalli Intensity (MMI) scale, and is probably incomplete because the region was sparsely populated. Seismograph networks did not start providing specific earthquake locations and magnitudes in the Pacific Northwest until about 1960.

Large earthquakes (magnitude greater than Richter 7) in the Pacific Northwest have occurred in the vicinity of Puget Sound, Washington, and near the Rocky Mountains in eastern Idaho and western Montana. A large earthquake of uncertain location occurred in north-central Washington in 1872. This event had an estimated maximum MMI ranging from VII to IX and an estimated Richter magnitude of approximately 7. The distribution of intensities suggests a location within a broad region between Lake Chelan, Washington, and the British Columbia border. Seismicity of the Columbia Basin subprovince of the Columbia Plateau province, as determined by the rate of earthquakes and the historical magnitude of these events, is low when compared to other regions of the Pacific Northwest. The largest earthquakes near the Hanford Site are two earthquakes that occurred in 1918 and 1973. These two events had magnitudes of 4.4 and intensity $\mathrm{V}$ and were located north of the Hanford Site. For more information concerning the seismology and geology of this area, see section 4.2.3 of the Hanford Site National Environmental Policy Act (NEPA) Characterization (Cushing 1992).

\subsubsection{Local Meteorology}

Continuous observation and recording of meteorological data has been carried out at the Hanford Meteorological Station (HMS), located near the 200 West Area, since 1945. Climatological conditions on the 200 Area plateau are significantly different from those on the south end of the Site, especially during the winter months when the incidence of low clouds and fog is much greater at the HMS.

The average daily maximum temperature in July, the hottest month of the year, is $33.2^{\circ} \mathrm{C}$ $\left(91.8^{\circ} \mathrm{F}\right)$; the average minimum is $16.1^{\circ} \mathrm{C}\left(61.0^{\circ} \mathrm{F}\right)$. During January, the coldest month, the average maximum is $2.6^{\circ} \mathrm{C}\left(36.6^{\circ} \mathrm{F}\right)$, and the average minimum is $-5.6^{\circ} \mathrm{C}\left(21.9^{\circ} \mathrm{F}\right)$. The daily temperature range is about $8.2^{\circ} \mathrm{C}\left(14.7^{\circ} \mathrm{F}\right)$ in January and $17.1^{\circ} \mathrm{C}\left(30.8^{\circ} \mathrm{F}\right)$ in July. 


\section{HNF-SD-PRP-HA-027, Rev. 2}

The average annual precipitation for the Hanford Site is about $16 \mathrm{~cm}$ (6.25 inches). Most of the precipitation occurs during the winter season with nearly half of the annual amount occurring in the months of November through February. Snowfall accounts for about $38 \%$ of all precipitation during the months of December through February.

The predominant wind direction over most of the region is southwesterly. However, because of local topographic influences, the predominant wind direction at the HMS and over much of the Hanford Site including the 200 Area Plateau is northwesterly. Monthly average wind speeds are lowest during the winter months, averaging 10 to $11 \mathrm{~km} / \mathrm{h}(6.2$ to $6.8 \mathrm{mph})$, and highest during the summer, averaging 14 to $16 \mathrm{~km} / \mathrm{h}$ (8.7 to $9.9 \mathrm{mph})$.

The Hanford Site is located in a semiarid region of southeastern Washington State. The Cascade Mountains beyond Yakima to the west greatly influence the climate of the Hanford Area by means of their rain shadow effect; this range also serves as a source of cold air drainage, which has a considerable effect on the wind regime on the Hanford Site.

\subsubsection{Wind and Tornado}

The Site is subject to frequent strong westerly winds. The all-time peak wind recorded at the HMS tower in the 200 West Area at the $15-\mathrm{m}$ level was a gust of $81 \mathrm{mph}$ recorded January 11,1972 . The $80 \mathrm{mph}$ gust is expected to occur once every 30 years. A peak of $85 \mathrm{mph}$ would be expected to occur once every 100 years (Cushing 1992).

The Site is well outside of established tornado alleys. The probability of a tornado in any year at any point within the 100 mile radius of the HMS is $6.8 \times 10^{-6} / \mathrm{yr}$ (Stone et al, 1983).

\subsubsection{Ashfall}

The Hanford Reservation is in a region subject to ashfall from volcanic eruptions. The three major volcanic peaks closest to the project are: Mt. Adams about $160 \mathrm{~km}(100 \mathrm{mi})$ away, Mt. Rainier at about $180 \mathrm{~km}(110 \mathrm{mi})$ away, and Mt. St. Helens approximately $210 \mathrm{~km}(130 \mathrm{mi})$ away.

Important historical ashfalls affecting this location were from eruptions of Glacier Peak about 12,000 B.P., Mt. Mazama about 6,000 B.P., and Mt. St. Helens about 3,600 B.P.. The most recent ashfall resulted from the May 18, 1980 eruption of Mt. St. Helens. The table below indicates the estimated ash depth deposited at the Hanford Site from past volcanic eruptions in the region. 
HNF-SD-PRP-HA-027, Rev. 2

Table 2.1 Estimated Ash Depth at Hanford from Major Eruptions

\begin{tabular}{||l|c|c|c|c||}
\hline \multirow{2}{*}{ Volcano } & \multirow{2}{*}{ Time } & \multirow{2}{*}{ Depth of Ash } & \multicolumn{2}{c||}{ Equivalent Roof Loading } \\
\cline { 3 - 5 } & & & Dry (psf) & Wet (psf) \\
\hline Glacier Peak & 12,000 B.P & 1 in & 6 & 8.4 \\
\hline Mt Mazama & 6,000 B.P. & 6 in & 36 & 50 \\
\hline Mt. St. Helens & 3,600 B.P. & 1 in & 6 & 8.4 \\
\hline Mt. St. Helens & 1980 & 0.5 in & 3 & 4.2 \\
\hline
\end{tabular}

B.P. - Before Present

\subsection{WRAP Configuration}

The descriptions were taken from the WRAP Final Safety Analysis Report (WMH, 1998).

WRAP consists of three structures housing process and process support systems and various utility systems. The main structure, $2336 \mathrm{~W}$, is a single pre-engineered metal building with a ground floor and a partial second floor. The structure is a beam and column type typically supplied by pre-engineered metal building manufacturers. The building houses process and process support systems as well as various services and utility systems. The facility design includes controlled access to potentially hazardous areas as well as segregation of administrative and other support personnel from operations and process activities.

The main structure or processing building, contains about $4,766 \mathrm{~m}^{2}\left(51,300 \mathrm{ft}^{2}\right)$ of total floor space. The building consists of the following areas: a shipping and receiving area, an administrative area; a personnel support area; a waste process area; a nondestructive examination (NDE) and nondestructive assay area (NEA), a process HVAC area; and a control and computer area (see figure 2.3). The following subsections describe each of the areas within the main structure, $2336 \mathrm{~W}$.

Two buildings house maintenance $(2620 \mathrm{~W})$ and administrative support (2740W) functions. The support buildings are subject to the normal hazards associated with industrial buildings and are not part of this analysis except as they are impacted by operations in the processing building.

\subsubsection{Administrative Area}

The administrative area is located at the building entrance and functions to control entry to the facility and houses some support staff.

\subsubsection{Personnel Support Area}

The personnel support area consists of the change room facilities, which are located off the main traffic path to the operational areas. Change rooms are sized to accommodate 60 operations personnel. 
HNF-SD-PRP-HA-027, Rev. 2

Figure 2.3 WRAP Layout - First Floor Plan.
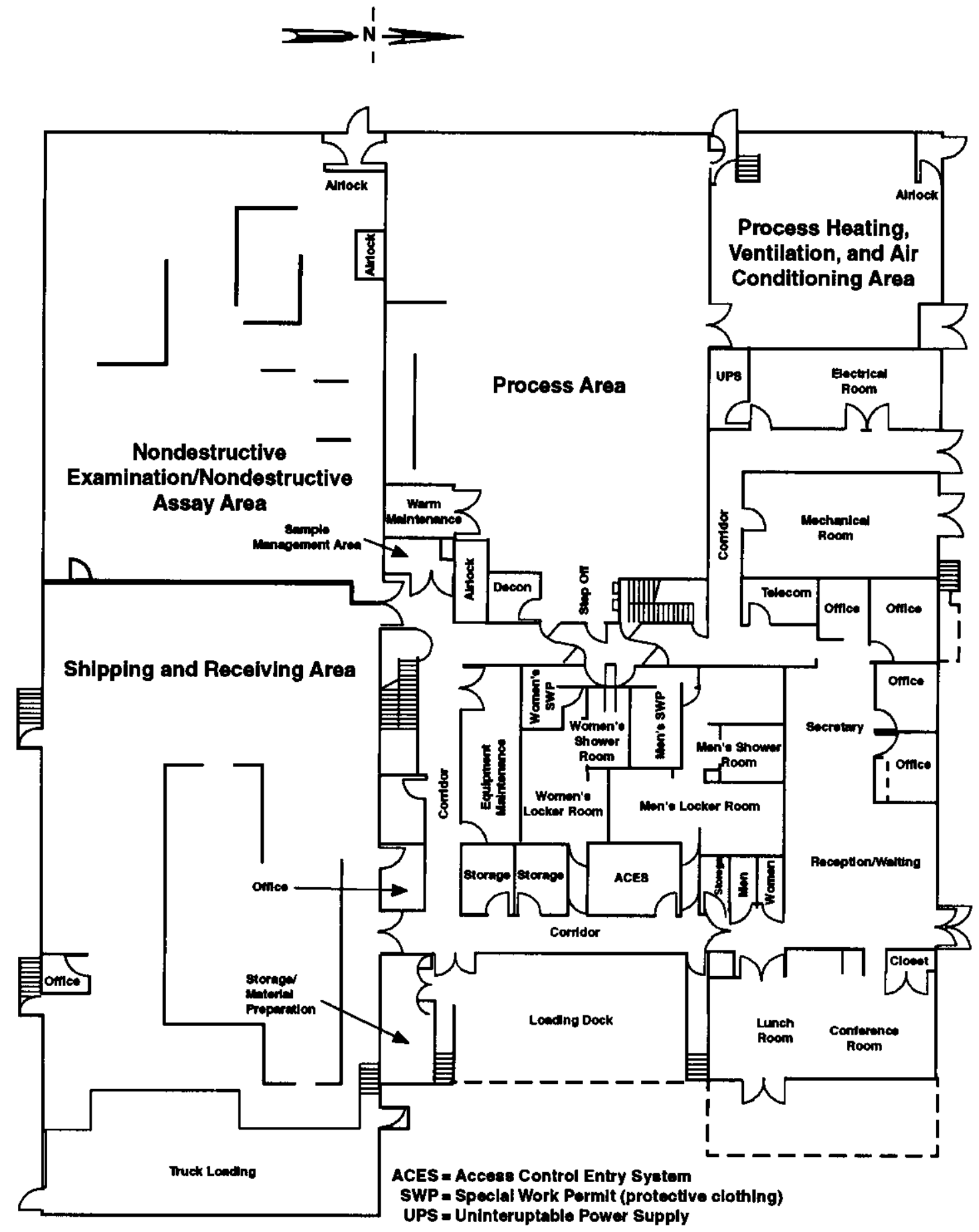


\section{HNF-SD-PRP-HA-027, Rev. 2}

\subsubsection{Shipping and Receiving Area}

The shipping and receiving area occupies the southeast corner of the facility and is entered off the main traffic corridor. The finish floor elevation of the area is $121.9 \mathrm{~cm}$ (48 in) above the adjacent exterior grade to accommodate two dock height waste unloading stations, and a depressed drive-through bay to serve the TRU packaging transporter (TRUPACT) II container loading. An Automated Stacker/Retrieval System (AS/RS) for drum storage located in the shipping and receiving area. Additional drum storage is provided in the TRUPACT II loading area. Storage space for boxes is also available in the shipping/receiving room.

In the shipping and receiving area, personnel use fork trucks, drum handling equipment, conveyers, an overhead bridge crane, and jib cranes, to unload and move waste drums and boxes. An automated guided vehicle (AGV) is generally used to transport drums between the shipping and receiving area and the nondestructive examination (NDE)/nondestructive assay (NDA) area. Processed and certified TRU waste drums are loaded in TRUPACT II casks using an overhead crane. The casks are filled while still on the trailer. Processed LLW containers are loaded onto trucks at the loading dock for storage or burial at the Hanford Site.

\subsubsection{Nondestructive Examination/Nondestructive Assay Area}

The NDE/NDA area is located in the southwest corner of the facility and is typically entered from the shipping and receiving area. In addition to the NDE and NDA stations, the area is equipped for the storage of up to 12 drums going to, or coming from, the process area or shipping and receiving area. Airlocks are provided to facilitate the transfer of drums by conveyers into the controlled process area and to provide emergency personnel egress from the NDE/NDA and process areas.

Waste drums and boxes are examined and assayed in the NDE/NDA area. Waste boxes are transported by forklift and drums are transported by the AGV or manually from the shipping and receiving area to the NDE/NDA equipment. The NDE/NDA equipment consists of:

- NDE station for boxes

- NDA station for boxes

- NDE stations for drums (2)

- Passive/action neutron (PAN) stations for drums (2)

- Gamma energy assay (GEA) stations for drums (2).

\subsubsection{Waste Process Area}

Waste drums are processed in four process enclosure lines. The TRU enclosure line consists of enclosure sections where drums enter, are opened and emptied; empty drums are compacted; packets are subjected to assay and X-ray; noncompliant items are removed; waste is repackaged; and the repackaged drums are loaded out. The LLW enclosure line operations are similar to those in the TRU enclosure line except drum super compaction can be performed after repackaging. There are two RWM enclosure lines, one for TRU-containing restricted waste and one for LLW. Noncompliant items removed from drums in the process enclosure are sent to the 


\section{HNF-SD-PRP-HA-027, Rev. 2}

appropriate RWM enclosure line. The TRU RWM enclosure line and the LLW RWM enclosure line sample, process, and repackage these noncompliant waste forms. The processed waste drums from all four enclosures lines are transported back through the airlock to the NDE/NDA area and then to shipping and receiving for shipment to a storage or disposal facility.

The process area serves as secondary containment when waste drums are opened. Personnel routes into and out of the area is restricted to step-off areas and process airlocks. Waste drums routinely enter and leave the process area through the airlock located in the NDE/NDA area. An additional nonpersonnel airlock is provided for the transfer of sample containers between the process area and the sample management office.

\subsubsection{Process HVAC Area}

The process HVAC area is located adjacent to the process area and contains the exhaust fans and high efficiency particulate air (HEPA) filtration equipment associated with the process area. A $2.4 \times 4.9-\mathrm{m}(8 \times 16-\mathrm{ft})$ removable exterior wall panel is provided in the exterior wall for equipment and material movements during maintenance and decommissioning. Two emergency personnel exits through airlocks are provided directly to the outside.

The process HVAC area contains two Zone I and two Zone II ventilation exhaust systems. These exhaust systems provide the ventilation confinement zones to the process enclosures and the process areas, ensuring any airborne contamination flows from less contaminated to more contaminated areas. Each exhaust system consists of plenums, two stages of HEPA filtration, exhaust fans and associated valves, instruments, and controls.

\subsubsection{Control and Computer Area}

The control and computer area contains operator consoles for NDE/NDA transport, dispatcher functions, facility alarm annunciator, printers, central processing units and miscellaneous supporting elements.

The control and computer rooms are located on the upper level of the facility. This location permits direct observation of the shipping and receiving, NDE/NDA, and process areas.

\subsection{WRAP Basic Process Description}

WRAP processes LLW and TRU waste that can be handled without radiation shielding (i.e., contact-handled wastes with radioactive dose rates less than $2 \mathrm{mSv} / \mathrm{hr}$ [ $200 \mathrm{mrem} / \mathrm{hr}]$ at any point on the waste container, although containers with higher dose rates may be processed under approved procedures). 
The facility is designed to receive a maximum of 40 waste drums per day and 2 waste boxes per week. Drums are typically received in the shipping and receiving area, transferred to a containment pallet and stored. Before entering the NDE/NDA area, each drum is removed from the pallet and weighed and its bar code is read. The weight label is confirmed or corrected.

Information about the received waste containers is entered into the WRAP Data Management System (DMS). Weight information is used to calculate specific TRU activity and to identify containers that exceed weight limits established in the waste acceptance criteria.

All waste drums and boxes received at WRAP are subjected to NDE/NDA to verify compliance with waste certification requirements and (in the case of drums) determine the appropriate method for processing any restricted waste present.

If an incoming waste container has completed NDE/NDA assessment and is certified for disposal, it is returned to the shipping and receiving areas, and prepared for shipment. All waste drums found through NDE/NDA to contain restricted waste are sent to the waste processing area or returned to storage pending treatment at an appropriate facility, if WRAP processing is not appropriate for the contents. In addition, waste drums that contain certified waste that are to be repackaged or supercompacted are sent to waste processing. LLW drums that meet the appropriate disposal criteria can be directly supercompacted to reduce the waste volume.

In the waste processing area, waste drums that do not meet appropriate disposal criteria are opened and sorted to remove or process the restricted waste. Two process enclosure lines are provided to perform these waste processing operations: one is dedicated to TRU waste and the other to LLW. The two process enclosure lines and their associated equipment are segregated to prevent cross-contamination of LLW with TRU waste material.

In the sorting process, specific hazardous materials and other regulated waste (e.g., lead bricks, polychlorinated biphenyls) that cannot be processed at WRAP to a disposable form are either left in the drum or removed from the drum for repackaging. In either case, the drums containing the nondisposable material are shipped to continued storage pending future treatment.

Restricted waste items that are segregated and placed in containers in the waste process enclosures are transferred to the restricted waste management (RWM) enclosures. One RWM enclosure is dedicated to LLW and the other to TRU waste material to avoid the possibility of cross contamination. Samples of restricted waste items are obtained for analysis in each RWM enclosure. The RWM enclosures also provide limited restricted waste processing capabilities such as absorption of small quantities of liquids, immobilization of particulates, and depressurization of aerosol cans.

After processing, all outgoing waste drums undergo NDA and NDE if necessary for final certification before shipment. 


\section{HNF-SD-PRP-HA-027, Rev. 2}

\subsection{IDENTIFICATION AND SCREENING OF HAZARDS}

Emergency Planning and Community Right-to-Know Act legislation indicate that Title 40 of the Code of Federal Regulations (CFR) 355 Appendix A and 10 CFR 30.72 Schedule C provide the Threshold Planning Quantity (TPQ) for extremely hazardous substances and radioactive materials for which emergency planning will be implemented. These lists are not entirely inclusive. Other hazardous materials may exist in sufficient quantity which when released to the environment may pose public health hazards to Hanford workers and the general public.

\subsection{Chemical Hazards}

Process chemicals and materials that may be stored and used in WRAP include neutralizing agents, processing agents, and decontamination agents. These materials are stored in color coded 1-qt containers in segregated storage racks in the RWM process enclosures.

Bulk chemicals and materials are stored in the chemical storage area. Up to 3801 (100 gal) each of sulfuric acid, nitric acid and sodium hydroxide may be stored in the area. At this time these chemicals are not yet present within the facility. In addition, up to $450 \mathrm{~kg}(1,000 \mathrm{lb})$ of cement additives, $225 \mathrm{~kg}(500 \mathrm{lb})$ of diatomaceous earth or vermiculite and $45 \mathrm{~kg}(100 \mathrm{lb})$ of a fixative polymer may be stored in the area as well.

In addition to the process chemicals and materials, small quantities of various hazardous materials may be used during routine facility maintenance.

Many of the packages handled at the facility will contain various amounts of hazardous chemicals. Table 3.1, taken from the WRAP Final Safety Analysis Report (WMH, 1998) provides an indication of the types and quantities of hazardous materials contained in the retrieved waste feedstream. 


\section{HNF-SD-PRP-HA-027, Rev. 2}

Table 3.1 Hazardous Material Components

\begin{tabular}{|c|c|c|c|c|}
\hline Component & $\begin{array}{l}\text { Total number } \\
\text { of containers }\end{array}$ & $\begin{array}{l}\text { Number of containers } \\
\text { with amounts listed }\end{array}$ & $\begin{array}{c}\text { Maximum amount } \\
\text { in one container } \\
(\mathrm{kg})\end{array}$ & $\begin{array}{l}\text { Median } \\
(\mathrm{kg})\end{array}$ \\
\hline Ammonia & 5 & 5 & 0.4500 & 0.4500 \\
\hline Ammonium nitrate & 3 & 3 & 7.8900 & 7.4400 \\
\hline Beryllium & 1,006 & 118 & 7.0000 & 1.8144 \\
\hline Cadmium & 159 & 157 & 89.9923 & 0.0003 \\
\hline Cyclohexane & 6 & 4 & 3.7500 & 2.2200 \\
\hline Dioxane & 2 & 1 & 25.2196 & 25.2196 \\
\hline Hydrogen peroxide & 4 & 4 & 0.4999 & 0.1000 \\
\hline Indole-2-C14 picrate & 1 & 1 & $<0.0001$ & $<0.0001$ \\
\hline Manganese & 2 & 2 & 0.0600 & 0.0400 \\
\hline Mercury & 220 & 184 & 43.5446 & 0.0410 \\
\hline Napthylamine tritium & 1 & 1 & 102.0600 & 102.0600 \\
\hline Nitric acid & 177 & 149 & 34.9990 & 0.0200 \\
\hline Phosphoric acid & 205 & 44 & 49.9856 & 2.9996 \\
\hline Propane & 1 & 1 & 0.8999 & 0.8999 \\
\hline Sodium & 7 & 2 & 2.5601 & 1.2821 \\
\hline Sodium hydroxide & 3,030 & 3,011 & 37.1900 & 0.0004 \\
\hline Sodium hypochlorite & 1 & 1 & 0.0075 & 0.0075 \\
\hline Sodium oxide & 16 & 16 & 48.2600 & 48.2600 \\
\hline Styrene/styrene monomer & 6 & 6 & 2.7501 & 0.5561 \\
\hline Tetrahydrofuran & 6 & 6 & 1.3499 & 0.0007 \\
\hline Tetralin & 1 & 1 & $<0.0001$ & $<0.0001$ \\
\hline Uranyl nitrate hexahydrate & 7 & 7 & 6.1099 & 0.6999 \\
\hline Vinyl ester/acetate resins & 4 & 4 & 2.7501 & 0.9500 \\
\hline Vinyl chloride/resins & 11 & 11 & 4.0960 & 0.4536 \\
\hline Zirconium & 752 & 187 & 0.8600 & 11.6421 \\
\hline
\end{tabular}

Several of the chemicals in the table are listed in 40 CFR 355 Appendix A but the quantities are well below the TPQs. Chemical hazards associated with the waste will not be evaluated further. 


\section{HNF-SD-PRP-HA-027, Rev. 2}

\subsection{Radiological Hazards}

(WHM 1998).

The following information was taken from the WRAP Final Safety Analysis Report

WRAP will receive drums and boxes of waste from past and present DOE activities. WRAP will receive the following waste types.

- Contact-handled waste. Packaged waste with an external surface radiation dose rate not exceeding 200 millirem per hour (WHC-EP-0063-04).

- $\quad$ TRU waste. DOE Order 5820.2A, Radioactive Waste Management, defines TRU waste without regard to source or form, as waste that is contaminated with alphaemitting transuranic radionuclides with half-lives greater than 20 years and concentrations greater than 100 nanocuries per gram at the time of assay. A transuranic radionuclide is any radionuclide having an atomic number greater than 92.

- $\quad$ Suspect TRU waste. Waste believed to be contaminated with TRU radionuclides but not yet assayed to determine whether the concentration of TRU radionuclides is greater than 100 nanocuries per gram

- LLW. Waste that contains radioactivity and is not classified as high-level waste, TRU waste, or spent nuclear fuel or byproduct material as defined by DOE Order $5820.2 \mathrm{~A}$.

- Retrieved waste. Waste that has been retrievably stored since 1970 or later in either below-ground storage trenches or aboveground structures. This waste has limited available documentation on hazardous material content.

- Newly generated waste. Waste that has been certified as to content by an onsite generating unit or an offsite generator.

- Restricted waste. Waste that exhibits characteristics or contains items not in compliance with either the requirements as noted in Hanford Site and Waste Isolation Pilot Plant criteria for waste acceptance, transportation, and final disposal (WIPP-DOE-069) or Washington State Department of Ecology (Ecology) Dangerous Waste Regulations, Washington Administrative Code (WAC) 173-303.

- $\quad$ Mixed waste. As defined in WAC 173-303.

- Dangerous waste. As defined in WAC 173-303. 


\section{HNF-SD-PRP-HA-027, Rev. 2}

Waste received at WRAP could fall into more than one of these categories. Approximately 38 percent of the total WRAP feed stream is expected to consist of containers of suspect TRU waste from 55 onsite and offsite generators that were placed in retrievable storage between 1970 and 1990.

The analysis in chapter 3.0 of the WRAP Final Safety Analysis Report (WMH 1998), assumed all waste packages to be one of the following four types.

1. Average 208-liter TRU drum

TRU $=11$ grams

$\mathrm{MFP}=0.07$ curie with the following isotopic contributions:

$\begin{array}{ll}\text { cesium-137 } & 24.80 \text { percent } \\ \text { barium-137m } & 24.80 \text { percent } \\ \text { strontium-90 } & 19.40 \text { percent } \\ \text { yttrium-90 } & 19.40 \text { percent. }\end{array}$

2. Maximum 208-liter TRU drum

TRU $=\quad 200.0$ grams

$\mathrm{MFP}=\quad 0.07$ curie with the same isotopic contributions as the average TRU drum.

3. Standard waste box

$$
\begin{array}{ll}
\text { TRU }= & 325.0 \text { grams } \\
\text { MFP }= & \begin{array}{l}
0.07 \text { curies with the same isotopic contributions as the average } \\
\text { TRU drum. }
\end{array}
\end{array}
$$

4. Wood waste box

$$
\begin{aligned}
& \text { TRU }=0.0 \text { gram } \\
& \text { MFP }=35.0 \text { DE-Ci }\left(\mathrm{DE}^{239} \mathrm{Pu}\right) .
\end{aligned}
$$

The total assumed inventory of waste containers and their locations are as follows:

- In the shipping and receiving area, the AS/RS can hold up to 216 drums. Up to 112 drums could be on the conveyor awaiting shipment in the TRUPACT storage area, while as many as 40 additional drums could be in miscellaneous locations such as conveyors and pallet transfer points. There are storage positions for 8 boxes. 


\section{HNF-SD-PRP-HA-027, Rev. 2}

- The NDE/NDA area is designated for storage of up to 12 drums going to or coming from the process area. Six drums and 2 SWBs could be positioned in examination stations and two additional drums could be on conveyors for transfer to the process area.

- In the process area, the designated area for temporary RWM drum storage has a capacity for up to 24 drums. Twenty additional drums could be present on conveyors awaiting entry to or removal from the process enclosures.

One maximum TRU drum is listed as part of the 368 in the shipping and receiving storage. There is a total of 431 average TRU drums, one maximum TRU drum, and 10 SWBs. Note, for conservatism, all boxes are assumed to be metal SWBs containing the maximum allowed 325 grams TRU. Total grams of TRU possibly present in WRAP would be:

$$
\begin{array}{ll}
431 \text { drums x } 11 \text { grams per drum }= & 4,741 \text { grams } \\
1 \text { drum } \times 200 \text { grams per drum }= & 200 \text { grams } \\
10 \text { boxes } \times 325 \text { grams per SWB }= & \frac{3,250 \text { grams }}{8,191 \text { grams }}
\end{array}
$$

While the MFP concentrations associated with the TRU containers are relatively small and MFP consequences are significantly less than TRU (for the same activity released), WRAP will also process LLW containers with larger quantities of MFP. Waste acceptance criteria limit the amount of radioactivity in the waste packages. The most restrictive limit is that associated with ${ }^{90} \mathrm{Sr}$ and is $550 \mathrm{TBq}(15,000 \mathrm{Ci})$ per $\mathrm{m}^{3}$ of waste. Based on this, it is theoretically possible to receive a $0.208 \mathrm{~m}^{3}$ (55-gallon) drum that contains $115 \mathrm{TBq}(3120 \mathrm{Ci})$ of ${ }^{90} \mathrm{Sr}$.

Both the TRU and MFP inventories for WRAP exceed the screening thresholds presented in 10 CFR 30.72, Schedule $C$ and will require further analysis.

\subsection{HAZARD CHARACTERIZATION}

\subsection{Toxicological Hazards}

The screening process described in the preceding section identified several chemicals and materials that may be stored in bulk quantities in the facility. Of the items identified, only nitric acid and sulfuric acid are listed in Appendix A of 40 CFR 355. Both of these chemicals will be maintained in quantities less than their TPQ of 1,000 pounds.

\subsection{Radiological Hazards}

The screening process described in the proceeding section identified TRU and MFP as warranting further characterization. As TRU is primarily composed of plutonium and americium, these elements are briefly characterized below. The MFP is nominally a mix of strontium and cesium however, only strontium will be evaluated in the release calculations. 


\section{HNF-SD-PRP-HA-027, Rev. 2}

\subsubsection{Plutonium}

The plutonium $(\mathrm{Pu})$ contained in Hanford Site wastes originated from reprocessing of discharged fuel from the nine Hanford Site production reactors over a period of approximately 45 years. The fissile isotope ${ }^{239} \mathrm{Pu}$ was the main plutonium isotope of interest. However, in making ${ }^{239} \mathrm{Pu}$, other isotopes of plutonium are created as well through the $\mathrm{n}$-gamma $(\mathrm{n}$,$) reaction,$ including the undesirable nonfissile ${ }^{240} \mathrm{Pu}$. The mass ratio of the plutonium isotopes is a function of the reactor, fuel burn-up, and decay time.

Two types of plutonium, differentiated by the amount of ${ }^{240} \mathrm{Pu}$, were produced at the Hanford Site. Fuels grade plutonium produced at the Hanford Site is nominally 12 percent ${ }^{240} \mathrm{Pu}$. Weapons grade plutonium is nominally 6 percent ${ }^{240} \mathrm{Pu}$. The 12 percent plutonium-240 distribution has higher potential radiological consequences than 6 percent plutonium-240. Table 4.1, derived from the SAR, characterizes a conservative worst case TRU makeup.

Absorption of plutonium from the gastrointestinal tract is low. Data emphasize the complexity of the retention of plutonium compounds in the lung. Plutonium absorbed in the blood stream is deposited principally in the liver and skeleton.

\subsubsection{Americium}

The radioisotope ${ }^{241}$ americium (Am) is a potentially major contributor to an inhalation or ingestion dose from TRU waste. It is the beta decay product of ${ }^{241} \mathrm{Pu}$. Although it takes approximately 70 years to reach transient equilibrium, 95 percent of the peak health hazard occurs approximately 20 years after discharge from the reactor.

Experiments on animals indicate that compounds of americium are more rapidly cleared from the lung and absorbed from the gastrointestinal tract than are compounds of plutonium. Like plutonium, americium settles primarily in the bone and liver. The ICRP model assumes americium to be uniformly distributed over the bone surfaces at all times following its deposition in the skeleton.

Table 4.1 TRU $12 \%$ (Nominal) ${ }^{240} \mathrm{Pu}, 20$-yr Aged

\begin{tabular}{||c|c|c|c|c||}
\hline Isotope & Weight $\%$ & $\begin{array}{c}\text { Specific activity } \\
(\mathrm{Ci} / \mathrm{g})\end{array}$ & $\mathrm{Ci}$ & $\mathrm{Bq}$ \\
\hline${ }^{238} \mathrm{Pu}$ & 0.08 & $1.71 \mathrm{E}+01$ & $1.37 \mathrm{E}-02$ & $5.07 \mathrm{E}+08$ \\
\hline${ }^{239} \mathrm{Pu}$ & 83.95 & $6.20 \mathrm{E}-02$ & $5.20 \mathrm{E}-02$ & $1.92 \mathrm{E}+09$ \\
\hline${ }^{240} \mathrm{Pu}$ & 12.97 & $2.27 \mathrm{E}-01$ & $2.94 \mathrm{E}-02$ & $1.09 \mathrm{E}+09$ \\
\hline${ }^{241} \mathrm{Pu}$ & 1.1 & $1.03 \mathrm{E}+02$ & $1.13 \mathrm{E}+00$ & $4.18 \mathrm{E}+10$ \\
\hline${ }^{242} \mathrm{Pu}$ & 0.03 & $3.93 \mathrm{E}-03$ & $1.17 \mathrm{E}-06$ & $4.33 \mathrm{E}+04$ \\
\hline${ }^{241} \mathrm{Am}$ & 1.75 & $3.42 \mathrm{E}+00$ & $5.99 \mathrm{E}-02$ & $2.22 \mathrm{E}+09$ \\
\hline
\end{tabular}




\section{HNF-SD-PRP-HA-027, Rev. 2}

\subsubsection{Strontium and Cesium}

Since most of the High Level Waste (HLW) at the Hanford Site is 25 to 50 years old, ${ }^{90}$ strontium (Sr) and ${ }^{137}$ cesium (Cs) are the dominant fission product radiological health hazards at this point in time. Both are beta emitters with half-lives of approximately 30 years.

Additionally, both ${ }^{90} \mathrm{Sr}$ and ${ }^{137} \mathrm{Cs}$ have relatively short half-life daughters that rapidly build up to equilibrium concentrations with the parent nuclides. This means that before the parent is significantly decayed or expelled from the body, the daughter products have reached equilibrium concentrations. The daughter of ${ }^{137} \mathrm{Cs}$ is the metastable isotope ${ }^{137 \mathrm{~m}} \mathrm{Ba}$, which emits a $0.662-\mathrm{MeV}$ gamma-ray in its decay to stable ${ }^{137} \mathrm{Ba}$. This gamma-ray is the dominant external penetrating radiation hazard in almost all radiation transport calculations involving Hanford Site HLW. Compared to the inhalation dose of ${ }^{137} \mathrm{Cs} /{ }^{137 m} \mathrm{Ba},{ }^{137 \mathrm{~m}} \mathrm{Ba}$ is also a significant contributor to dose through ground shine.

The daughter of ${ }^{90} \mathrm{Sr}$ is ${ }^{90} \mathrm{Y}$, which is a beta emitter. Because of its relatively short halflife (64 hours), ${ }^{90} \mathrm{Y}$ builds up to secular equilibrium within days. Since the submersion dose due to a respirable aerosol cloud of ${ }^{90} \mathrm{Sr} /{ }^{90} \mathrm{Y}$ is more than 10,000 times less than the dose due to the inhaled aerosols, ${ }^{90} \mathrm{Sr}$ and ${ }^{90} \mathrm{Y}$ are primarily inhalation hazards.

Cesium is rapidly and almost completely absorbed into the blood and cleared from the lung. Available evidence indicates that cesium is distributed uniformly in the body. Strontium is also easily absorbed and cleared and primarily settles in the bone. The International Commission on Radiological Protection ICRP-30 (ICRP 1979) model assumes ${ }^{90} \mathrm{Sr}$ to be evenly distributed throughout the bone.

\subsection{Radioactive Material Confinement}

The confinement system during normal operations and anticipated operational occurrences in the waste process area consists of the process enclosures and their ventilation systems (primary barriers). Secondary confinement for the enclosures consists of the building structure enclosing the waste process area and its associated ventilation system. In areas other than the waste process enclosure lines, where waste drums and boxes containing hazardous materials will not be opened, but will be handled and/or stored, the containers, including any required liners, provide primary confinement. Secondary confinement is provided by the building structure. 
HNF-SD-PRP-HA-027, Rev. 2

\subsection{CONSEQUENCE MODELS, RECEPTOR LOCATIONS AND CLASSIFICATION CRITERIA}

\subsection{Consequence Model}

Radiological consequences were estimated using the Hanford Unified Dose Utility (HUDU) computer code (Scherpelz 1991). This code is the primary emergency response tool used at the Unified Dose Assessment Center (UDAC) for evaluating radiological releases on the Hanford Site.

HUDU employs a straight line Gaussian plume model and Pasquill-Gifford stability classes. Release source terms considered only the respirable fraction. Release of radionuclides into the environment are either elevated (effective release height is $>2.5$ times the building height) or ground level. By convention, release heights less than 10 meters default to ground level releases. In these analyses building wake effects and plume rise are not considered, producing conservative dose estimates. The HUDU code does not incorporate plume depletion.

\subsection{Meteorological Conditions}

In order to determine the proper event classification for each scenario analyzed, consequences are calculated for a severe meteorological condition. For the purposes of this assessment severe meteorology is assumed to be $F$ stability and $1 \mathrm{~m} / \mathrm{s}$ wind speed. To be conservative, and unless otherwise noted, all releases were modeled as ground level open air (i.e., no building wake effects). To create information which will be useful for response personnel, calculations are also performed for a wind speed of $1 \mathrm{~m} / \mathrm{s}$ and D and A stability classes. The following assumptions were made for the mixing layer depth for each of the stability classes used, $A=300 \mathrm{~m}, D=200 \mathrm{~m}$ and $\mathrm{F}=60 \mathrm{~m}$. The results provide information that can be rapidly scaled by responders in the initial stages of response to estimate consequences for the current meteorological conditions.

\subsection{Receptor Locations}

Two receptor locations are evaluated for purposes of comparing with the emergency classification criteria: A maximum onsite individual at the facility boundary and a maximum off site individual at the offsite boundary.

The facility boundary distance used in the following analyses is $100 \mathrm{~m}$. The nearest Hanford Site boundary to the WRAP is 11.7 kilometers $(7.25$ miles) distant. For purposes of emergency planning, the nearest shore of the Columbia River is treated as site boundary when it is closer than the actual site boundary. The nearest shore of the Columbia River is about 8.7 kilometers ( 5.4 miles) to the north.

In addition, a receptor located at Washington State Highway 240 will be evaluated because of the potential for an unaware motorist to be exposed to released materials from WRAP events. This distance is $5 \mathrm{~km}$ ( 3.1 miles). 


\section{HNF-SD-PRP-HA-027, Rev. 2}

\subsection{Emergency Classification Criteria}

A goal of the DOE emergency preparedness system is to quickly classify the severity of an accident. Preplanned actions are then implemented for each emergency class. Emergency classification is based, in part, on projected TEDE and hazardous material concentrations at the facility and Hanford Site boundaries for pre analyzed accident scenarios. The emergency classification criteria are shown below.

\section{Table 5.1 Radiological Release Criteria}

Emerg. Class

Alert

Site Area

General

\section{Criteria}

$>0.001 \mathrm{~Sv}$ (100 mrem) TEDE at the facility boundary

$\geq 0.01 \mathrm{~Sv}$ (1 rem) TEDE at the facility boundary

$\geq 0.01 \mathrm{~Sv}$ (1 rem) TEDE at the site boundary

Table 5.2 Non-Radiological Release Criteria

Emerg. Class

Alert

Site Area

General
Criteria

$>$ ERPG 1 at facility boundary

$\geq$ ERPG 2 at facility boundary

$\geq$ ERPG 2 at site boundary

The non-radiological release criteria apply to a peak concentration of the substance in air. If Emergency Response Planning Guideline (ERPG) values have not been established for a substance, alternative criteria specified in the Emergency Management Guide for Hazards Assessments shall be used (DOE 1997).

There are also general criteria for emergency classification in addition to the numerical values in the tables above. The threshold between reportable occurrences and the Alert classification is difficult to establish based solely on a numerical value. The following general criteria apply in addition to the dose commitment and airborne release concentration values specified in the tables above.

\section{ALERT}

An ALERT Emergency shall be declared when events are in progress or have occurred which involve an actual or potential substantial degradation of the level of safety of the facility with an increased potential for a release.

In general, the ALERT classification is appropriate when the severity and/or complexity of an event may exceed the capabilities of the normal operating organization to adequately manage the event and its consequences. 


\section{HNF-SD-PRP-HA-027, Rev. 2}

\section{SITE AREA}

A SITE AREA Emergency shall be declared when events are in progress or have occurred which involve actual or likely major failures of facility functions needed for protection of workers and the public.

\section{GENERAL}

A GENERAL Emergency shall be declared when events are in progress or have occurred that involve actual or imminent catastrophic failure of facility safety systems with a potential for loss of confinement or containment integrity.

There is additional emergency classification guidance in the Emergency Management Guide on Event Classification and Emergency Action Levels. The Hazards Assessment in the following sections is based primarily on a comparison of calculated consequences with the numerical criteria in the tables above. However, some recommendations are provided based on the more general emergency classification criteria.

\subsection{EVENT SCENARIOS AND CONSEQUENCES}

Accidents can originate as a result of facility operations, natural phenomena, and from deliberate outside interventions (security contingencies). The majority of these accidents initiate fires, explosions or spills leading to environmental releases as described in this section and the WRAP Final Safety Analysis Report (WMH, 1998).

\subsection{Radiological Releases}

Chapter 3.0, of the WRAP Final Safety Analysis Report (WMH 1998) postulates a variety of events. The following assumptions are included in the Final Safety Analysis Report (WMH 1998) and will be used in this assessment. At least one drum in each drum release scenario (except for seismic events because a TSR requires that all drums containing more than 100 grams of TRU be stored in the bottom tier so are not subject to falling from heights greater than four-feet) contains 200 grams of TRU. Scenarios involving 30 drums or less assume 75 grams of TRU per drum. Accidents involving more than 30 drums assume 11 grams of TRU per drum. SWBs contain 325 grams of TRU. The Final Safety Analysis Report (WMH, 1998) contains no similar type information for the LLW drums so this assessment will assume that any $\mathrm{LLW}$ drum involved in the events contains the maximum allowed quantity of $115 \mathrm{TBq}(3120 \mathrm{Ci})$ of ${ }^{90} \mathrm{Sr}$.

The basis for airborne release fractions (ARF) and respirable fractions used in Chapter 3.0 of the WRAP Final Safety Analysis Report (WMH 1998) is Airborne Release Fractions/Rates and Respirable Fractions for Non-Reactor Nuclear Facilities, DOE-HDBK3010-94 (DOE, 1994). The respirable release fraction for drum or SWB drops of more than 1 meter is 1.0E-06 (assumes a leak path factor based on the lid being damaged but still pretty much 


\section{HNF-SD-PRP-HA-027, Rev. 2}

intact), the respirable release fraction for a drum crush is $1.0 \mathrm{E}-05$ and the respirable release fraction for drum punctures is $1.0 \mathrm{E}-06$. The respirable release fraction for combustion of packaged waste is $5.0 \mathrm{E}-04$, for uncontained combustible materials it is $1.0 \mathrm{E}-02$ and for heating contaminated non combustible solids it is $6.0 \mathrm{E}-05$. The respirable release fraction for explosions is $1.0 \mathrm{E}-03$. The respirable release fraction for a HEPA filter crush is $5.0 \mathrm{E}-04$, for thermal stress of the HEPA it is 1.0E-04 and for a HEPA blowout it is $2.0 \mathrm{E}-06$.

To simplify the TRU calculations, a one gram release of TRU aged 20 years, as shown in Table 4-1, was modeled with HUDU assuming a ground level release with a $1 \mathrm{~m} / \mathrm{sec}(2.2 \mathrm{mph})$ wind speed and stability class F. Multiplying the source term in grams for a TRU accident scenario by the results will provide the dose at each receptor location. The results are as follows:

Table 6.1 $1 \mathrm{gram}$ Release of TRU

\begin{tabular}{||c||c|c||c|c||c|c||}
\hline \multirow{2}{*}{ Receptor } & \multicolumn{2}{c||}{ A Stability Class } & \multicolumn{2}{c||}{ D Stability Class } & \multicolumn{2}{c||}{ F Stability Class } \\
\cline { 2 - 7 } & $\begin{array}{c}\text { TEDE } \\
\text { Sv/gm }\end{array}$ & $\begin{array}{c}\text { TEDE } \\
\text { Rem/gm }\end{array}$ & $\begin{array}{c}\text { TEDE } \\
\text { Sv/gm }\end{array}$ & $\begin{array}{c}\text { TEDE } \\
\text { Rem/gm }\end{array}$ & $\begin{array}{c}\text { TEDE } \\
\text { Sv/gm }\end{array}$ & $\begin{array}{c}\text { TEDE } \\
\text { Rem/gm }\end{array}$ \\
\hline \hline Onsite & $1.9 \mathrm{E}-01$ & $1.9 \mathrm{E}+01$ & 1.5 & $1.5 \mathrm{E}+02$ & 6.2 & $6.2 \mathrm{E}+02$ \\
\hline HWY240 & $3.4 \mathrm{E}-04$ & $3.4 \mathrm{E}-02$ & $1.4 \mathrm{E}-03$ & $1.4 \mathrm{E}-01$ & $1.2 \mathrm{E}-02$ & 1.2 \\
\hline Offsite & $2.0 \mathrm{E}-04$ & $2.0 \mathrm{E}-02$ & $1.0 \mathrm{E}-03$ & $1.0 \mathrm{E}-01$ & $5.9 \mathrm{E}-03$ & $5.9 \mathrm{E}-01$ \\
\hline
\end{tabular}

Based on these results, an airborne respirable release of 1.6E-04 grams of TRU will meet the ALERT Emergency criteria, 1.6E-03 grams release will meet SITE AREA Emergency criteria and a 1.7 grams release will meet GENERAL Emergency criteria.

The WRAP Final Safety Analysis Report (WMH 1998) does not specifically evaluate any accidents involving MFP since a worst case TRU event would bound any worst case MFP event. In emergency planning, a wider spectrum of accidents (both less severe and more severe) than design basis need to be evaluated to provide the basis for a graded emergency response program, so MFP events will be considered as well.

To simplify the MFP calculations, a 3.7E-02 TBq $(1 \mathrm{Ci})$ release of ${ }^{90} \mathrm{Sr}$ and an equivalent amount of ${ }^{90} \mathrm{Y}$ was modeled with HUDU assuming a ground level release with a $1 \mathrm{~m} / \mathrm{sec}(2.2$ $\mathrm{mph}$ ) wind speed and F Stability class. Multiplying the source term in Ci for a MFP accident scenario by the results will provide the dose at each receptor location. The results are as follows: 


\section{HNF-SD-PRP-HA-027, Rev. 2}

Table 6.2 1 Ci Release of MFP

\begin{tabular}{||c||c|c||c|c||c|c||}
\hline \multirow{2}{*}{ Receptor } & \multicolumn{2}{c||}{ A Stability Class } & \multicolumn{2}{c||}{ D Stability Class } & \multicolumn{2}{c||}{ F Stability Class } \\
\cline { 2 - 7 } & $\begin{array}{c}\text { TEDE } \\
\text { Sv/Ci }\end{array}$ & $\begin{array}{c}\text { TEDE } \\
\text { Rem/Ci }\end{array}$ & $\begin{array}{c}\text { TEDE } \\
\text { Sv/Ci }\end{array}$ & $\begin{array}{c}\text { TEDE } \\
\text { Rem/Ci }\end{array}$ & $\begin{array}{c}\text { TEDE } \\
\text { Sv/Ci }\end{array}$ & $\begin{array}{c}\text { TEDE } \\
\text { Rem/Ci }\end{array}$ \\
\hline \hline Onsite & $6.7 \mathrm{E}-04$ & $6.7 \mathrm{E}-02$ & $5.2 \mathrm{E}-03$ & $5.2 \mathrm{E}-01$ & $2.2 \mathrm{E}-02$ & 2.2 \\
\hline HWY240 & $1.2 \mathrm{E}-06$ & $1.2 \mathrm{E}-04$ & $7.8 \mathrm{E}-06$ & $7.8 \mathrm{E}-04$ & $4.1 \mathrm{E}-05$ & $4.1 \mathrm{E}-03$ \\
\hline Offsite & $7.0 \mathrm{E}-07$ & $7.0 \mathrm{E}-05$ & $3.5 \mathrm{E}-06$ & $3.5 \mathrm{E}-04$ & $2.1 \mathrm{E}-05$ & $2.1 \mathrm{E}-03$ \\
\hline
\end{tabular}

Based on these results, an airborne respirable release of $1.68 \mathrm{GBq}(4.55 \mathrm{E}-02 \mathrm{Ci})$ will meet the ALERT Emergency criteria, $9 \mathrm{TBq}(4.55 \mathrm{E}-01 \mathrm{Ci})$ release will meet SITE AREA Emergency criteria and a $17.625 \mathrm{TBq}(4.76 \mathrm{E}+02 \mathrm{Ci})$ release will meet GENERAL Emergency criteria.

\subsubsection{NDE/NDA or Shipping and Receiving Area Spill}

TRU Drums A pallet of four drums in the shipping and receiving or NDE/NDA areas is tipped over. Two drums lose their lids as they are impacted by the other two. One drum is assumed to contain the maximum 200 grams TRU and the other contains the 95th percentile quantity of 75 grams. The airborne respirable release fraction is $1.0 \mathrm{E}-06$. For this accident, it is assumed that the doors are left open and that the material is released directly to the environment. The net release is 2.75E-04 grams. Following are the TEDEs for this event.

Table 6.3 TRU Drum Spill TEDEs

\begin{tabular}{||c||c|c|c|c||c|c||}
\hline \multirow{2}{*}{ Receptor } & \multicolumn{2}{c|}{ A Stability Class } & \multicolumn{2}{c||}{ D Stability Class } & \multicolumn{2}{c||}{ F Stability Class } \\
\cline { 2 - 7 } & $\begin{array}{c}\text { TEDE } \\
\text { Sv }\end{array}$ & $\begin{array}{c}\text { TEDE } \\
\text { Rem }\end{array}$ & $\begin{array}{c}\text { TEDE } \\
\text { Sv }\end{array}$ & $\begin{array}{c}\text { TEDE } \\
\text { Rem }\end{array}$ & $\begin{array}{c}\text { TEDE } \\
\text { Sv }\end{array}$ & $\begin{array}{c}\text { TEDE } \\
\text { Rem }\end{array}$ \\
\hline \hline Onsite & $5.23 \mathrm{E}-05$ & $5.23 \mathrm{E}-03$ & $4.13 \mathrm{E}-04$ & $4.13 \mathrm{E}-02$ & $1.71 \mathrm{E}-03$ & $1.71 \mathrm{E}-01$ \\
\hline HWY240 & $9.35 \mathrm{E}-08$ & $9.35 \mathrm{E}-06$ & $3.85 \mathrm{E}-07$ & $3.85 \mathrm{E}-05$ & $3.30 \mathrm{E}-06$ & $3.30 \mathrm{E}-04$ \\
\hline Offsite & $5.50 \mathrm{E}-08$ & $5.50 \mathrm{E}-06$ & $2.75 \mathrm{E}-07$ & $2.75 \mathrm{E}-05$ & $1.62 \mathrm{E}-06$ & $1.62 \mathrm{E}-04$ \\
\hline
\end{tabular}




\section{HNF-SD-PRP-HA-027, Rev. 2}

For the three conditions analyzed above, the approximate distances at which the EPA Protective Action Guide (PAG) of $0.01 \mathrm{~Sv}$ (1 rem) is exceeded are as follows:

Table 6.4 TRU Drum Spill PAG Distance

\begin{tabular}{||c|c|c|c|}
\hline \multicolumn{4}{|c|}{ Approximate Distance at Which PAG (1 rem) Exceeded } \\
\hline \hline Distance & A Stability & D Stability & F Stability \\
\hline \hline Kilometers & $<0.10$ & $<0.10$ & $<0.10$ \\
\hline Miles & $<0.06$ & $<0.06$ & $<0.06$ \\
\hline
\end{tabular}

The results of this analysis indicate that under severe meteorological conditions this event would meet the criteria for classification as an ALERT, greater than $0.001 \mathrm{~Sv}(100 \mathrm{mrem})$ at the facility boundary, but less than $0.01 \mathrm{~Sv}(1 \mathrm{rem})$ at the site boundary.

LLW Drums For the same accident involving LLW drums, the net release is $23 \mathrm{MBq}$ $(0.00624 \mathrm{Ci})$. Following are the TEDEs for this event.

Table 6.5 LLW Drum Spill TEDEs

\begin{tabular}{|c|c|c|c|c|c|c|}
\hline \multirow{2}{*}{ Receptor } & \multicolumn{2}{|c|}{ A Stability Class } & \multicolumn{2}{|c|}{ D Stability Class } & \multicolumn{2}{|c|}{ F Stability Class } \\
\hline & $\begin{array}{c}\text { TEDE } \\
\text { Sv }\end{array}$ & $\begin{array}{c}\text { TEDE } \\
\text { Rem }\end{array}$ & $\begin{array}{c}\text { TEDE } \\
\text { Sv }\end{array}$ & $\begin{array}{c}\text { TEDE } \\
\text { Rem }\end{array}$ & $\begin{array}{c}\text { TEDE } \\
\text { Sv }\end{array}$ & $\begin{array}{c}\text { TEDE } \\
\text { Rem }\end{array}$ \\
\hline Onsite & $4.18 \mathrm{E}-06$ & $4.18 \mathrm{E}-04$ & $3.24 \mathrm{E}-05$ & $3.24 \mathrm{E}-03$ & 1.37E-04 & $1.37 \mathrm{E}-02$ \\
\hline HWY240 & 7.49E-09 & $7.49 \mathrm{E}-07$ & 4.87E-08 & 4.87E-06 & $2.56 \mathrm{E}-07$ & $2.56 \mathrm{E}-05$ \\
\hline Offsite & 4.37E-09 & 4.37E-07 & $2.18 \mathrm{E}-08$ & $2.18 \mathrm{E}-06$ & $1.31 \mathrm{E}-07$ & 1.31E-05 \\
\hline
\end{tabular}

For the three conditions analyzed above, the approximate distances at which the EPA Protective Action Guide (PAG) of $0.01 \mathrm{~Sv}(1 \mathrm{rem})$ is exceeded are as follows:

Table 6.6 LLW Drum Spill PAG Distances

\begin{tabular}{|c|c|c|c||}
\hline \multicolumn{3}{|c|}{ Approximate Distance at Which PAG (1 rem) Exceeded } \\
\hline Distance & A Stability & D Stability & F Stability \\
\hline \hline Kilometers & $<0.10$ & $<0.10$ & $<0.10$ \\
\hline Miles & $<0.06$ & $<0.06$ & $<0.06$ \\
\hline
\end{tabular}

The results of this analysis indicate that under severe meteorological conditions this event would not meet the criteria for classification as an Operational Emergency. 


\section{HNF-SD-PRP-HA-027, Rev. 2}

SWB The release from a single SWB is $3.25 \mathrm{E}-04$ grams. Following are the TEDEs for this event.

Table 6.7 TRU SWB Spill TEDEs

\begin{tabular}{||c||c|c||c|c||c|c||}
\hline \multirow{2}{*}{ Receptor } & \multicolumn{2}{|c||}{ A Stability Class } & \multicolumn{2}{c||}{ D Stability Class } & \multicolumn{2}{c||}{ F Stability Class } \\
\cline { 2 - 7 } & $\begin{array}{c}\text { TEDE } \\
\text { Sv }\end{array}$ & $\begin{array}{c}\text { TEDE } \\
\text { Rem }\end{array}$ & $\begin{array}{c}\text { TEDE } \\
\text { Sv }\end{array}$ & $\begin{array}{c}\text { TEDE } \\
\text { Rem }\end{array}$ & $\begin{array}{c}\text { TEDE } \\
\text { Sv }\end{array}$ & $\begin{array}{c}\text { TEDE } \\
\text { Rem }\end{array}$ \\
\hline \hline Onsite & $6.18 \mathrm{E}-05$ & $6.18 \mathrm{E}-03$ & $4.88 \mathrm{E}-04$ & $4.88 \mathrm{E}-02$ & $2.02 \mathrm{E}-03$ & $2.02 \mathrm{E}-01$ \\
\hline HWY240 & $1.11 \mathrm{E}-07$ & $1.11 \mathrm{E}-05$ & $4.55 \mathrm{E}-07$ & $4.55 \mathrm{E}-05$ & $3.90 \mathrm{E}-06$ & $3.90 \mathrm{E}-04$ \\
\hline Offsite & $6.50 \mathrm{E}-08$ & $6.50 \mathrm{E}-06$ & $3.25 \mathrm{E}-07$ & $3.25 \mathrm{E}-05$ & $1.92 \mathrm{E}-06$ & $1.92 \mathrm{E}-04$ \\
\hline
\end{tabular}

For the three conditions analyzed above, the approximate distances at which the EPA Protective Action Guide (PAG) of $0.01 \mathrm{~Sv}(1 \mathrm{rem})$ is exceeded are as follows:

\section{Table 6.8 TRU SWB Spill PAG Distances}

\begin{tabular}{|c|c|c|c|}
\hline \multicolumn{4}{|c|}{ Approximate Distance at Which PAG (1 rem) Exceeded } \\
\hline Distance & A Stability & D Stability & F Stability \\
\hline Kilometers & $<0.10$ & $<0.10$ & $<0.10$ \\
\hline Miles & $<0.06$ & $<0.06$ & $<0.06$ \\
\hline
\end{tabular}

The results of this analysis indicate that under severe meteorological conditions this event would meet the criteria for classification as an ALERT, greater than $0.001 \mathrm{~Sv}(100 \mathrm{mrem})$ at the facility boundary, but less than $0.01 \mathrm{~Sv}$ (1 rem) at the Site Boundary.

\subsubsection{NDE/NDA or Shipping and Receiving Area Drum Spill w/Fire}

Similar to the first scenario except that the drums catch fire. A total of $65 \%$ of the contents are consumed with a release fraction of 5.0E-04 the remaining $35 \%$ has a release fraction of $6.0 \mathrm{E}-05$ for heating non-combustible materials. Again, doors are assumed to be open so the release is directly to the environment.

TRU The release from the combustion is added to the mechanical release in the following manner:

$(275)(1 \mathrm{E}-6)+(275-.000275)[(.65)(5 \mathrm{E}-4)+(.35)(6 \mathrm{E}-5)]=9.54 \mathrm{E}-02$ grams. 


\section{HNF-SD-PRP-HA-027, Rev. 2}

Following are the TEDEs for this event.

Table 6.9 NDE/NDA Shipping and Receiving Area Drum Spill w/Fire TEDEs

\begin{tabular}{|c||c|c||c|c||c|c||}
\hline \multirow{2}{*}{ Receptor } & \multicolumn{2}{|c||}{ A Stability Class } & \multicolumn{2}{c||}{ D Stability Class } & \multicolumn{2}{c||}{ F Stability Class } \\
\cline { 2 - 7 } & $\begin{array}{c}\text { TEDE } \\
\text { Sv }\end{array}$ & $\begin{array}{c}\text { TEDE } \\
\text { Rem }\end{array}$ & $\begin{array}{c}\text { TEDE } \\
\text { Sv }\end{array}$ & $\begin{array}{c}\text { TEDE } \\
\text { Rem }\end{array}$ & $\begin{array}{c}\text { TEDE } \\
\text { Sv }\end{array}$ & $\begin{array}{c}\text { TEDE } \\
\text { Rem }\end{array}$ \\
\hline \hline Onsite & $1.81 \mathrm{E}-02$ & $1.81 \mathrm{E}-00$ & $1.43 \mathrm{E}-01$ & $1.43 \mathrm{E}+01$ & $5.91 \mathrm{E}-01$ & $5.91 \mathrm{E}+01$ \\
\hline HWY240 & $3.24 \mathrm{E}-05$ & $3.24 \mathrm{E}-03$ & $1.34 \mathrm{E}-04$ & $1.34 \mathrm{E}-02$ & $1.14 \mathrm{E}-03$ & $1.14 \mathrm{E}-01$ \\
\hline Offsite & $1.91 \mathrm{E}-05$ & $1.91 \mathrm{E}-03$ & $9.54 \mathrm{E}-05$ & $9.54 \mathrm{E}-03$ & $5.63 \mathrm{E}-04$ & $5.63 \mathrm{E}-02$ \\
\hline
\end{tabular}

For the three conditions analyzed above, the approximate distances at which the EPA Protective Action Guide (PAG) of $0.01 \mathrm{~Sv}$ (1 rem) is exceeded are as follows:

Table 6.10 NDE/NDA Shipping and Receiving Area Drum Spill w/Fire PAG Distances

\begin{tabular}{||c|c|c|c||}
\hline \multicolumn{4}{|c|}{ Approximate Distance at Which PAG (1 rem) Exceeded } \\
\hline Distance & A Stability & D Stability & F Stability \\
\hline Kilometers & 0.16 & 0.48 & 1.29 \\
\hline Miles & 0.10 & 0.30 & 0.80 \\
\hline
\end{tabular}

The results of this analysis indicate that under severe meteorological conditions this event would meet the criteria for classification as a SITE AREA Emergency, greater than $0.01 \mathrm{~Sv}$ (1 rem) at the facility boundary, but less than $0.01 \mathrm{~Sv}(1 \mathrm{rem})$ at the Site Boundary.

LLW An identical event involving LLW drums releases:

$(6240 \mathrm{Ci})(1 \mathrm{E}-6)+(6240-.00624)[(.65)(5 \mathrm{E}-4)+(.35)(6 \mathrm{E}-5)]=2.17 \mathrm{Ci}$

Following are the TEDEs for this event.

Table 6.11 LLW Drum Fire TEDEs

\begin{tabular}{||c||c|c||c|c||c|c||}
\hline \multirow{3}{*}{ Receptor } & \multicolumn{2}{c||}{ A Stability Class } & \multicolumn{2}{c|}{ D Stability Class } & \multicolumn{2}{c||}{ F Stability Class } \\
\cline { 2 - 7 } & $\begin{array}{c}\text { TEDE } \\
\text { Sv }\end{array}$ & $\begin{array}{c}\text { TEDE } \\
\text { Rem }\end{array}$ & $\begin{array}{c}\text { TEDE } \\
\text { Sv }\end{array}$ & $\begin{array}{c}\text { TEDE } \\
\text { Rem }\end{array}$ & $\begin{array}{c}\text { TEDE } \\
\text { Sv }\end{array}$ & $\begin{array}{c}\text { TEDE } \\
\text { Rem }\end{array}$ \\
\hline \hline Onsite & $1.45 \mathrm{E}-03$ & $1.45 \mathrm{E}-01$ & $1.13 \mathrm{E}-02$ & $1.13 \mathrm{E}+00$ & $4.77 \mathrm{E}-02$ & $4.77 \mathrm{E}+00$ \\
\hline HWY240 & $2.60 \mathrm{E}-06$ & $2.60 \mathrm{E}-04$ & $1.69 \mathrm{E}-05$ & $1.69 \mathrm{E}-03$ & $8.90 \mathrm{E}-05$ & $8.90 \mathrm{E}-03$ \\
\hline Offsite & $1.52 \mathrm{E}-06$ & $1.52 \mathrm{E}-04$ & $7.60 \mathrm{E}-06$ & $7.60 \mathrm{E}-04$ & $4.56 \mathrm{E}-05$ & $4.56 \mathrm{E}-03$ \\
\hline
\end{tabular}

For the three conditions analyzed above, the approximate distances at which the EPA Protective Action Guide (PAG) of $0.01 \mathrm{~Sv}$ (1 rem) is exceeded are as follows: 


\section{HNF-SD-PRP-HA-027, Rev. 2}

Table 6.12 LLW Drum Fire PAG Distances

\begin{tabular}{||c|c|c|c|}
\hline \multicolumn{4}{|c|}{ Approximate Distance at Which PAG (1 rem) Exceeded } \\
\hline Distance & A Stability & D Stability & F Stability \\
\hline \hline Kilometers & $<0.10$ & 0.16 & 0.32 \\
\hline Miles & $<0.06$ & 0.10 & 0.20 \\
\hline
\end{tabular}

The results of this analysis indicate that under severe meteorological conditions this event would meet the criteria for classification as a SITE AREA Emergency, greater than $0.01 \mathrm{~Sv}$ (1 rem) at the facility boundary, but less than $0.01 \mathrm{~Sv}(1 \mathrm{rem})$ at the Site Boundary.

\subsubsection{NDE/NDA or Shipping and Receiving Area Drum Explosion}

Two scenarios involving a drum explosion are analyzed. In the first, a drum containing 200 grams of TRU or $3120 \mathrm{Ci}$ of ${ }^{90} \mathrm{Sr}$ explodes in the shipping and receiving or NDA/NDE areas. Ten percent of the drum's contents are ejected with a 1.0E-03 respirable release fraction.

$200[(.1)(1 \mathrm{E}-3)]=2.00 \mathrm{E}-02$ grams.

Similarly, the ${ }^{90} \mathrm{Sr}$ release is: $3.12 \mathrm{E}-01 \mathrm{Ci}$.

Doors are assumed to be open so the release is directly to the environment.

Following are the TEDEs for this event.

Table 6.13 TRU Drum Explosion TEDEs

\begin{tabular}{|c||c|c||c|c||c|c||}
\hline \multirow{2}{*}{ Receptor } & \multicolumn{2}{|c||}{ A Stability Class } & \multicolumn{2}{c||}{ D Stability Class } & \multicolumn{2}{c||}{ F Stability Class } \\
\cline { 2 - 7 } & $\begin{array}{c}\text { TEDE } \\
\text { Sv }\end{array}$ & $\begin{array}{c}\text { TEDE } \\
\text { Rem }\end{array}$ & $\begin{array}{c}\text { TEDE } \\
\text { Sv }\end{array}$ & $\begin{array}{c}\text { TEDE } \\
\text { Rem }\end{array}$ & $\begin{array}{c}\text { TEDE } \\
\text { Sv }\end{array}$ & $\begin{array}{c}\text { TEDE } \\
\text { Rem }\end{array}$ \\
\hline Onsite & $3.80 \mathrm{E}-03$ & $3.80 \mathrm{E}-01$ & $3.00 \mathrm{E}-02$ & $3.00 \mathrm{E}+00$ & $1.24 \mathrm{E}-01$ & $1.24 \mathrm{E}+01$ \\
\hline HWY240 & $6.80 \mathrm{E}-06$ & $6.80 \mathrm{E}-04$ & $2.80 \mathrm{E}-05$ & $2.80 \mathrm{E}-03$ & $2.40 \mathrm{E}-04$ & $2.40 \mathrm{E}-02$ \\
\hline Offsite & $4.00 \mathrm{E}-06$ & $4.00 \mathrm{E}-04$ & $2.00 \mathrm{E}-05$ & $2.00 \mathrm{E}-03$ & $1.18 \mathrm{E}-04$ & $1.18 \mathrm{E}-02$ \\
\hline
\end{tabular}




\section{HNF-SD-PRP-HA-027, Rev. 2}

For the three conditions analyzed above, the approximate distances at which the EPA Protective Action Guide (PAG) of $0.01 \mathrm{~Sv}$ (1 rem) is exceeded are as follows:

\section{Table 6.14 TRU Drum Explosion PAG Distances}

\begin{tabular}{||c|c|c|c|}
\hline \multicolumn{4}{|c|}{ Approximate Distance at Which PAG (1 rem) Exceeded } \\
\hline \hline Distance & A Stability & D Stability & F Stability \\
\hline \hline Kilometers & 0.10 & 0.16 & 0.48 \\
\hline Miles & $<0.06$ & 0.10 & 0.30 \\
\hline
\end{tabular}

The results of this analysis indicate that under severe meteorological conditions this event would meet the criteria for classification as a Site Area Emergency, greater than $0.01 \mathrm{~Sv}$ (1 rem) at the facility boundary, but less than $0.01 \mathrm{~Sv}(1 \mathrm{rem})$ at the Site Boundary.

Table 6.15 LLW Drum Explosion TEDEs

\begin{tabular}{|c||c|c||c|c|c|c||}
\hline \multirow{2}{*}{ Receptor } & \multicolumn{2}{|c||}{ A Stability Class } & \multicolumn{2}{c|}{ D Stability Class } & \multicolumn{2}{c||}{ F Stability Class } \\
\cline { 2 - 7 } & $\begin{array}{c}\text { TEDE } \\
\text { Sv }\end{array}$ & $\begin{array}{c}\text { TEDE } \\
\text { Rem }\end{array}$ & $\begin{array}{c}\text { TEDE } \\
\text { Sv }\end{array}$ & $\begin{array}{c}\text { TEDE } \\
\text { Rem }\end{array}$ & $\begin{array}{c}\text { TEDE } \\
\text { Sv }\end{array}$ & $\begin{array}{c}\text { TEDE } \\
\text { Rem }\end{array}$ \\
\hline \hline Onsite & $2.09 \mathrm{E}-04$ & $2.09 \mathrm{E}-02$ & $1.62 \mathrm{E}-03$ & $1.62 \mathrm{E}-01$ & $6.86 \mathrm{E}-03$ & $6.86 \mathrm{E}-01$ \\
\hline HWY240 & $3.74 \mathrm{E}-07$ & $3.74 \mathrm{E}-05$ & $2.43 \mathrm{E}-06$ & $2.43 \mathrm{E}-04$ & $1.28 \mathrm{E}-05$ & $1.28 \mathrm{E}-03$ \\
\hline Offsite & $2.18 \mathrm{E}-07$ & $2.18 \mathrm{E}-05$ & $1.09 \mathrm{E}-06$ & $1.09 \mathrm{E}-04$ & $6.55 \mathrm{E}-06$ & $6.55 \mathrm{E}-04$ \\
\hline
\end{tabular}

For the three conditions analyzed above, the approximate distances at which the EPA Protective Action Guide (PAG) of $0.01 \mathrm{~Sv}(1 \mathrm{rem})$ is exceeded are as follows:

\section{Table 6.16 LLW Drum Explosion PAG Distances}

\begin{tabular}{|c|c|c|c|}
\hline \multicolumn{4}{|c|}{ Approximate Distance at Which PAG (1 rem) Exceeded } \\
\hline Distance & A Stability & D Stability & F Stability \\
\hline Kilometers & $<0.10$ & $<0.10$ & $<0.10$ \\
\hline Miles & $<0.06$ & $<0.06$ & $<0.06$ \\
\hline
\end{tabular}

The results of this analysis indicate that under severe meteorological conditions this event would meet the criteria for classification as an Alert, greater than $0.001 \mathrm{~Sv}(.1 \mathrm{rem})$ at the facility boundary, but less than $0.01 \mathrm{~Sv}$ (1 rem). 


\section{HNF-SD-PRP-HA-027, Rev. 2}

In the second scenario, the explosion is accompanied by a fire involving the drum contents. Of the remaining ejected material, $65 \%$ burns with a $1.0 \mathrm{E}-02$ release fraction and $35 \%$ is heated with a release fraction of $6.0 \mathrm{E}-05$. Of the $90 \%$ remaining in the drum, $65 \%$ burns with a release fraction of $5.0 \mathrm{E}-04$ and $35 \%$ is heated with a release fraction of $6.0 \mathrm{E}-05$. The TRU release is:

$200[(.1)(1 \mathrm{E}-3)+(.0999)((.65)(1 \mathrm{E}-2)+(.35)(6 \mathrm{E}-5))+(.9)((.65)(5 \mathrm{E}-4)+(.35)(6 \mathrm{E}-5))]=2.13 \mathrm{E}-01$ grams.

Similarly, the ${ }^{90} \mathrm{Sr}$ release is: $3.32 \mathrm{Ci}$.

Doors are assumed to be open so the release is directly to the environment.

Following are the TEDEs for this event.

Table 6.17 TRU Drum Explosion and Fire TEDEs

\begin{tabular}{||c||c|c||c|c||c|c||}
\hline \multirow{2}{*}{ Receptor } & \multicolumn{2}{c||}{ A Stability Class } & \multicolumn{2}{c||}{ D Stability Class } & \multicolumn{2}{c||}{ F Stability Class } \\
\cline { 2 - 7 } & $\begin{array}{c}\text { TEDE } \\
\text { Sv }\end{array}$ & $\begin{array}{c}\text { TEDE } \\
\text { Rem }\end{array}$ & $\begin{array}{c}\text { TEDE } \\
\text { Sv }\end{array}$ & $\begin{array}{c}\text { TEDE } \\
\text { Rem }\end{array}$ & $\begin{array}{c}\text { TEDE } \\
\text { Sv }\end{array}$ & $\begin{array}{c}\text { TEDE } \\
\text { Rem }\end{array}$ \\
\hline \hline Onsite & $4.05 \mathrm{E}-02$ & $4.05 \mathrm{E}+00$ & $3.20 \mathrm{E}-01$ & $3.20 \mathrm{E}+01$ & $1.32 \mathrm{E}+00$ & $1.32 \mathrm{E}+02$ \\
\hline HWY240 & $7.24 \mathrm{E}-05$ & $7.24 \mathrm{E}-03$ & $2.98 \mathrm{E}-04$ & $2.98 \mathrm{E}-02$ & $2.56 \mathrm{E}-03$ & $2.56 \mathrm{E}-01$ \\
\hline Offsite & $4.26 \mathrm{E}-05$ & $4.26 \mathrm{E}-03$ & $2.13 \mathrm{E}-04$ & $2.13 \mathrm{E}-02$ & $1.26 \mathrm{E}-03$ & $1.26 \mathrm{E}-01$ \\
\hline
\end{tabular}

For the three conditions analyzed above, the approximate distances at which the EPA Protective Action Guide (PAG) of $0.01 \mathrm{~Sv}(1 \mathrm{rem})$ is exceeded are as follows:

Table 6.18 TRU Drum Explosion and Fire PAG Distances

\begin{tabular}{|c|c|c|c|}
\hline \multicolumn{2}{|c|}{ Approximate Distance at Which PAG (1 rem) Exceeded } \\
\hline Distance & A Stability & D Stability & F Stability \\
\hline Kilometers & 0.16 & 0.81 & 2.09 \\
\hline Miles & 0.10 & 0.50 & 1.30 \\
\hline
\end{tabular}

The results of this analysis indicate that under severe meteorological conditions this event would meet the criteria for classification as a SITE AREA Emergency, greater than $0.01 \mathrm{~Sv}$ (1 rem) at the facility boundary, but less than $0.01 \mathrm{~Sv}(1 \mathrm{rem})$ at the Site Boundary. 


\section{HNF-SD-PRP-HA-027, Rev. 2}

Table 6.19 LLW Drum Explosion and Fire TEDEs

\begin{tabular}{||c||c|c||c|c||c|c||}
\hline \multirow{2}{*}{ Receptor } & \multicolumn{2}{|c||}{ A Stability Class } & \multicolumn{2}{c||}{ D Stability Class } & \multicolumn{2}{c||}{ F Stability Class } \\
\cline { 2 - 7 } & $\begin{array}{c}\text { TEDE } \\
\text { Sv }\end{array}$ & $\begin{array}{c}\text { TEDE } \\
\text { Rem }\end{array}$ & $\begin{array}{c}\text { TEDE } \\
\text { Sv }\end{array}$ & $\begin{array}{c}\text { TEDE } \\
\text { Rem }\end{array}$ & $\begin{array}{c}\text { TEDE } \\
\text { Sv }\end{array}$ & $\begin{array}{c}\text { TEDE } \\
\text { Rem }\end{array}$ \\
\hline \hline Onsite & $2.22 \mathrm{E}-03$ & $2.22 \mathrm{E}-01$ & $1.73 \mathrm{E}-02$ & $1.73 \mathrm{E}+00$ & $7.30 \mathrm{E}-02$ & $7.30 \mathrm{E}+00$ \\
\hline HWY240 & $3.89 \mathrm{E}-06$ & $3.89 \mathrm{E}-04$ & $2.59 \mathrm{E}-05$ & $2.59 \mathrm{E}-03$ & $1.36 \mathrm{E}-04$ & $1.36 \mathrm{E}-02$ \\
\hline Offsite & $2.32 \mathrm{E}-06$ & $2.32 \mathrm{E}-04$ & $1.16 \mathrm{E}-05$ & $1.16 \mathrm{E}-03$ & $6.97 \mathrm{E}-05$ & $6.97 \mathrm{E}-03$ \\
\hline
\end{tabular}

For the three conditions analyzed above, the approximate distances at which the EPA Protective Action Guide (PAG) of $0.01 \mathrm{~Sv}$ (1 rem) is exceeded are as follows:

Table 6.20 LLW Drum Explosion and Fire PAG Distances

\begin{tabular}{|c|c|c|c|}
\hline \multicolumn{4}{|c|}{ Approximate Distance at Which PAG (1 rem) Exceeded } \\
\hline Distance & A Stability & D Stability & F Stability \\
\hline Kilometers & $<0.10$ & 0.16 & 0.32 \\
\hline Miles & $<0.06$ & 0.10 & 0.20 \\
\hline
\end{tabular}

The results of this analysis indicate that under severe meteorological conditions this event would meet the criteria for classification as a SITE AREA Emergency, greater than $0.01 \mathrm{~Sv}$ (1 rem) at the facility boundary, but less than $0.01 \mathrm{~Sv}(1 \mathrm{rem})$ at the Site Boundary.

\subsubsection{Fire in Process Enclosures w/Filter Failure}

A drum containing 200 grams of TRU or $3120 \mathrm{Ci}$ of ${ }^{90} \mathrm{Sr}$ catches fire inside its process enclosure (glovebox). The heat from the fire also results in the destruction of the process enclosure HEPA filter (assumed to contain 5 grams TRU or $78 \mathrm{Ci}^{90} \mathrm{Sr}$ ) and the two stages of HEPA filters in the main ventilation system (assumed to contain 1 gram TRU or $15.6 \mathrm{Ci}{ }^{90} \mathrm{Sr}$ each). A total of $65 \%$ of the drum's contents are consumed with a release fraction of $5.0 \mathrm{E}-04$ the remaining $35 \%$ has a release fraction of $6.0 \mathrm{E}-05$ for heating non-combustible materials. The release fraction for the HEPA filters due to thermal stress is $1.0 \mathrm{E}-04$. The total TRU release is:

$200[(.65)(5 \mathrm{E}-4)+(.35)(6 \mathrm{E}-5)]+(7)(1 \mathrm{E}-4)=6.99 \mathrm{E}-02$ grams.

The total ${ }^{90} \mathrm{Sr}$ release is:

$3120[(.65)(5 \mathrm{E}-4)+(.35)(6 \mathrm{E}-5)]+(109)(1 \mathrm{E}-4)=1.09 \mathrm{E}+00 \mathrm{Ci}$. 


\section{HNF-SD-PRP-HA-027, Rev. 2}

Following are the TEDEs for this event.

Table 6.21 TRU Process Enclosure Fire TEDEs

\begin{tabular}{||c||c|c||c|c||c|c||}
\hline \multirow{2}{*}{ Receptor } & \multicolumn{2}{c||}{ A Stability Class } & \multicolumn{2}{c||}{ D Stability Class } & \multicolumn{2}{c||}{ F Stability Class } \\
\cline { 2 - 7 } & $\begin{array}{c}\text { TEDE } \\
\text { Sv }\end{array}$ & $\begin{array}{c}\text { TEDE } \\
\text { Rem }\end{array}$ & $\begin{array}{c}\text { TEDE } \\
\text { Sv }\end{array}$ & $\begin{array}{c}\text { TEDE } \\
\text { Rem }\end{array}$ & $\begin{array}{c}\text { TEDE } \\
\text { Sv }\end{array}$ & $\begin{array}{c}\text { TEDE } \\
\text { Rem }\end{array}$ \\
\hline \hline Onsite & $1.33 \mathrm{E}-02$ & $1.33 \mathrm{E}+00$ & $1.05 \mathrm{E}-01$ & $1.05 \mathrm{E}+01$ & $4.33 \mathrm{E}-01$ & $4.33 \mathrm{E}+01$ \\
\hline HWY240 & $2.38 \mathrm{E}-05$ & $2.38 \mathrm{E}-03$ & $9.79 \mathrm{E}-05$ & $9.79 \mathrm{E}-03$ & $8.39 \mathrm{E}-04$ & $8.39 \mathrm{E}-02$ \\
\hline Offsite & $1.40 \mathrm{E}-05$ & $1.40 \mathrm{E}-03$ & $6.99 \mathrm{E}-05$ & $6.99 \mathrm{E}-03$ & $4.12 \mathrm{E}-04$ & $4.12 \mathrm{E}-02$ \\
\hline
\end{tabular}

For the three conditions analyzed above, the approximate distances at which the EPA Protective Action Guide (PAG) of $0.01 \mathrm{~Sv}$ (1 rem) is exceeded are as follows:

Table 6.22 TRU Process Enclosure Fire PAG Distances

\begin{tabular}{||c|c|c|c||}
\hline \multicolumn{4}{|c||}{ Approximate Distance at Which PAG (1 rem) Exceeded } \\
\hline Distance & A Stability & D Stability & F Stability \\
\hline Kilometers & 0.16 & 0.32 & 1.13 \\
\hline Miles & 0.10 & 0.20 & 0.70 \\
\hline
\end{tabular}

The results of this analysis indicate that under severe meteorological conditions this event would meet the criteria for classification as a SITE AREA Emergency, greater than $0.01 \mathrm{~Sv}$ $(1 \mathrm{rem})$ at the facility boundary, but less than $0.01 \mathrm{~Sv}(1 \mathrm{rem})$ at the Site Boundary.

Table 6.23 LLW Process Enclosure Fire TEDEs

\begin{tabular}{||c||c|c||c|c||c|c||}
\hline \multirow{2}{*}{ Receptor } & \multicolumn{2}{c||}{ A Stability Class } & \multicolumn{2}{c||}{ D Stability Class } & \multicolumn{2}{c||}{ F Stability Class } \\
\cline { 2 - 7 } & $\begin{array}{c}\text { TEDE } \\
\text { Sv }\end{array}$ & $\begin{array}{c}\text { TEDE } \\
\text { Rem }\end{array}$ & $\begin{array}{c}\text { TEDE } \\
\text { Sv }\end{array}$ & $\begin{array}{c}\text { TEDE } \\
\text { Rem }\end{array}$ & $\begin{array}{c}\text { TEDE } \\
\text { Sv }\end{array}$ & $\begin{array}{c}\text { TEDE } \\
\text { Rem }\end{array}$ \\
\hline Onsite & $7.30 \mathrm{E}-04$ & $7.30 \mathrm{E}-02$ & $5.67 \mathrm{E}-03$ & $5.67 \mathrm{E}-01$ & $2.40 \mathrm{E}-02$ & $2.40 \mathrm{E}+00$ \\
\hline HWY240 & $1.31 \mathrm{E}-06$ & $1.31 \mathrm{E}-04$ & $8.50 \mathrm{E}-06$ & $8.50 \mathrm{E}-04$ & $4.47 \mathrm{E}-05$ & $4.47 \mathrm{E}-03$ \\
\hline Offsite & $7.63 \mathrm{E}-07$ & $7.63 \mathrm{E}-05$ & $3.83 \mathrm{E}-06$ & $3.83 \mathrm{E}-04$ & $2.29 \mathrm{E}-05$ & $2.29 \mathrm{E}-03$ \\
\hline
\end{tabular}




\section{HNF-SD-PRP-HA-027, Rev. 2}

For the three conditions analyzed above, the approximate distances at which the EPA Protective Action Guide (PAG) of $0.01 \mathrm{~Sv}$ ( $1 \mathrm{rem}$ ) is exceeded are as follows:

Table 6.24 LLW Process Enclosure Fire PAG Distances

\begin{tabular}{|c|c|c|c|}
\hline \multicolumn{4}{|c||}{ Approximate Distance at Which PAG (1 rem) Exceeded } \\
\hline Distance & A Stability & D Stability & F Stability \\
\hline \hline Kilometers & $<0.10$ & $<0.10$ & 0.16 \\
\hline Miles & $<0.06$ & $<0.06$ & 0.10 \\
\hline
\end{tabular}

The results of this analysis indicate that under severe meteorological conditions this event would meet the criteria for classification as a SITE AREA Emergency, greater than $0.01 \mathrm{~Sv}$ (1 rem) at the facility boundary, but less than $0.01 \mathrm{~Sv}(1 \mathrm{rem})$ at the Site Boundary.

\subsubsection{Drum Fire in TRU Process Enclosure w/Filter Intact}

This scenario is the same as 6.1.4 except that the final stage of HEPA filters remains intact and operates with a $99.95 \%$ efficiency. The reduction factor of 2000 will keep any release below emergency criteria levels.

\subsubsection{Drum Explosion in Process Enclosure w/Filter Failure}

This scenario assumes that an explosion occurs as the contents of a drum are being placed on the sorting table in the process enclosure (glovebox). Ten percent of the material is ejected with a $1.0 \mathrm{E}-03$ respirable release fraction. Of the remaining ejected material, $65 \%$ burns with a $1.0 \mathrm{E}-02$ release fraction and $35 \%$ is heated with a release fraction of $6.0 \mathrm{E}-05$. Of the $90 \%$ remaining on the table, $65 \%$ burns with a release fraction of $1.0 \mathrm{E}-02$ and $35 \%$ is heated with a release fraction of $6.0 \mathrm{E}-05$. The contribution from the failed filters is negligible for this case. The total TRU release is:

$200[(.1)(1 \mathrm{E}-3)+(.0999)((.65)(1 \mathrm{E}-2)+(.35)(6 \mathrm{E}-5))+(.9)((.65)(1 \mathrm{E}-2)+(.35)(6 \mathrm{E}-5))]=1.32$ grams.

Similarly, the ${ }^{90} \mathrm{Sr}$ release is $20.7 \mathrm{Ci}$. 


\section{HNF-SD-PRP-HA-027, Rev. 2}

Following are the TEDEs for this event.

Table 6.25 TRU Process Enclosure Explosion TEDEs

\begin{tabular}{||c||c|c||c|c||c|c||}
\hline \multirow{2}{*}{ Receptor } & \multicolumn{2}{c||}{ A Stability Class } & \multicolumn{2}{c||}{ D Stability Class } & \multicolumn{2}{c||}{ F Stability Class } \\
\cline { 2 - 7 } & $\begin{array}{c}\text { TEDE } \\
\text { Sv }\end{array}$ & $\begin{array}{c}\text { TEDE } \\
\text { Rem }\end{array}$ & $\begin{array}{c}\text { TEDE } \\
\text { Sv }\end{array}$ & $\begin{array}{c}\text { TEDE } \\
\text { Rem }\end{array}$ & $\begin{array}{c}\text { TEDE } \\
\text { Sv }\end{array}$ & $\begin{array}{c}\text { TEDE } \\
\text { Rem }\end{array}$ \\
\hline \hline Onsite & $2.51 \mathrm{E}-01$ & $2.51 \mathrm{E}+01$ & $1.98 \mathrm{E}+00$ & $1.98 \mathrm{E}+02$ & $8.18 \mathrm{E}+00$ & $8.18 \mathrm{E}+02$ \\
\hline HWY240 & $4.49 \mathrm{E}-04$ & $4.49 \mathrm{E}-02$ & $1.85 \mathrm{E}-03$ & $1.85 \mathrm{E}-01$ & $1.58 \mathrm{E}-02$ & $1.58 \mathrm{E}+00$ \\
\hline Offsite & $2.64 \mathrm{E}-04$ & $2.64 \mathrm{E}-02$ & $1.32 \mathrm{E}-03$ & $1.32 \mathrm{E}-01$ & $7.79 \mathrm{E}-03$ & $7.79 \mathrm{E}-01$ \\
\hline
\end{tabular}

For the three conditions analyzed above, the approximate distances at which the EPA Protective Action Guide (PAG) of $0.01 \mathrm{~Sv}(1 \mathrm{rem})$ is exceeded are as follows:

Table 6.26 TRU Process Enclosure Explosion PAG Distances

\begin{tabular}{||c|c|c|c||}
\hline \multicolumn{4}{|c|}{ Approximate Distance at Which PAG (1 rem) Exceeded } \\
\hline Distance & A Stability & D Stability & F Stability \\
\hline Kilometers & 0.48 & 0.10 & 7.40 \\
\hline Miles & 0.30 & 1.60 & 4.60 \\
\hline
\end{tabular}

The results of this analysis indicate that under severe meteorological conditions this event would meet the criteria for classification as a SITE AREA Emergency, greater than $0.01 \mathrm{~Sv}$ (1 rem) at the facility boundary, but less than $0.01 \mathrm{~Sv}(1 \mathrm{rem})$ at the Site Boundary.

Table 6.27 LLW Process Enclosure Explosion TEDEs

\begin{tabular}{||c||c|c||c|c||c|c||}
\hline \multirow{2}{*}{ Receptor } & \multicolumn{2}{c||}{ A Stability Class } & \multicolumn{2}{c||}{ D Stability Class } & \multicolumn{2}{c||}{ F Stability Class } \\
\cline { 2 - 7 } & $\begin{array}{c}\text { TEDE } \\
\text { Sv }\end{array}$ & $\begin{array}{c}\text { TEDE } \\
\text { Rem }\end{array}$ & $\begin{array}{c}\text { TEDE } \\
\text { Sv }\end{array}$ & $\begin{array}{c}\text { TEDE } \\
\text { Rem }\end{array}$ & $\begin{array}{c}\text { TEDE } \\
\text { Sv }\end{array}$ & $\begin{array}{c}\text { TEDE } \\
\text { Rem }\end{array}$ \\
\hline \hline Onsite & $1.39 \mathrm{E}-02$ & $1.39 \mathrm{E}+00$ & $1.08 \mathrm{E}-01$ & $1.08 \mathrm{E}+01$ & $4.55 \mathrm{E}-01$ & $4.55 \mathrm{E}+01$ \\
\hline HWY240 & $2.48 \mathrm{E}-05$ & $2.48 \mathrm{E}-03$ & $1.61 \mathrm{E}-04$ & $1.61 \mathrm{E}-02$ & $8.49 \mathrm{E}-04$ & $8.49 \mathrm{E}-02$ \\
\hline Offsite & $1.45 \mathrm{E}-05$ & $1.45 \mathrm{E}-03$ & $7.25 \mathrm{E}-05$ & $7.25 \mathrm{E}-03$ & $4.35 \mathrm{E}-04$ & $4.35 \mathrm{E}-02$ \\
\hline
\end{tabular}




\section{HNF-SD-PRP-HA-027, Rev. 2}

For the three conditions analyzed above, the approximate distances at which the EPA Protective Action Guide (PAG) of $0.01 \mathrm{~Sv}$ (1 rem) is exceeded are as follows:

\section{Table 6.28 LLW Process Enclosure Explosion PAG Distances}

\begin{tabular}{|c|c|c|c|}
\hline \multicolumn{4}{|c|}{ Approximate Distance at Which PAG (1 rem) Exceeded } \\
\hline Distance & A Stability & D Stability & F Stability \\
\hline \hline Kilometers & 0.16 & 0.32 & 1.13 \\
\hline Miles & 0.10 & 0.20 & 0.70 \\
\hline
\end{tabular}

The results of this analysis indicate that under severe meteorological conditions this event would meet the criteria for classification as a SITE AREA Emergency, greater than $0.01 \mathrm{~Sv}$ (1 $\mathrm{rem})$ at the facility boundary, but less than $0.01 \mathrm{~Sv}(1 \mathrm{rem})$ at the Site Boundary.

\subsubsection{Drum Explosion in Process Enclosure w/Filter Intact}

This scenario is the same as 6.1 .6 except that the final stage of HEPA filters remains intact and operates with a $99.95 \%$ efficiency. The reduction factor of 2000 will keep any release below emergency criteria levels.

\subsubsection{Seismic Event}

This event assumes that an earthquake causes 4 drums in the shipping and receiving area to fall. Three drums rupture and one drum, containing 100 grams (TSRs restrict the placement of drums containing more than 100 grams of TRU to the bottom tier so they are not susceptible to falls from any height while stored) of TRU explodes and causes all four to catch fire. A drum in the NDE/NDA area falls and is breached. In addition, a drum of waste on the sorting table in the TRU glovebox falls to the floor of the glovebox and glovebox confinement is breached. This scenario assumes that doors are open resulting in a direct release to the environment.

All drums contain 75 grams except for the one that explodes. For the material involved in the fire, $65 \%$ is burned with a release fraction of $5.0 \mathrm{E}-04$ and $35 \%$ has a release fraction of $6.0 \mathrm{E}-05$. The mechanical release fraction is $1.0 \mathrm{E}-06$. The mechanical TRU release is:

$$
(1 \mathrm{E}-6)^{*}(375)=3.75 \mathrm{E}-04 \text { grams }
$$

The combustion TRU release is:

$$
\left.(225-.000225)^{*}\left[(.65)^{*}(5 \mathrm{E}-4)+(.35)^{*} 6 \mathrm{E}-5\right)\right]=7.78 \mathrm{E}-02 \text { grams } .
$$

The explosion TRU release is 0.107 grams, half of that calculated in section 6.1.3. The total release is 0.185 grams. 


\section{HNF-SD-PRP-HA-027, Rev. 2}

For LLW, the mechanical release is:

$$
(1 \mathrm{E}-6)^{*}(15600)=0.0156 \mathrm{Ci}
$$

The combustion release is:

$$
\left.(9360-.00936) *\left[(.65)^{*}(5 \mathrm{E}-4)+(.35)^{*} 6 \mathrm{E}-5\right)\right]=3.24 \mathrm{Ci} .
$$

The explosion release is $3.32 \mathrm{Ci}$ from section 6.1.3. The total release is $6.58 \mathrm{Ci}$.

Following are the TEDEs for this event.

Table 6.29 Seismic Event TRU Release TEDEs

\begin{tabular}{||c||c|c|c|c||c|c||}
\hline \multirow{2}{*}{ Receptor } & \multicolumn{2}{|c|}{ A Stability Class } & \multicolumn{2}{c||}{ D Stability Class } & \multicolumn{2}{c||}{ F Stability Class } \\
\cline { 2 - 7 } & $\begin{array}{c}\text { TEDE } \\
\text { Sv }\end{array}$ & $\begin{array}{c}\text { TEDE } \\
\text { Rem }\end{array}$ & $\begin{array}{c}\text { TEDE } \\
\text { Sv }\end{array}$ & $\begin{array}{c}\text { TEDE } \\
\text { Rem }\end{array}$ & $\begin{array}{c}\text { TEDE } \\
\text { Sv }\end{array}$ & $\begin{array}{c}\text { TEDE } \\
\text { Rem }\end{array}$ \\
\hline \hline Onsite & $3.52 \mathrm{E}-02$ & $3.52 \mathrm{E}+00$ & $2.78 \mathrm{E}-01$ & $2.78 \mathrm{E}+01$ & $1.15 \mathrm{E}+00$ & $1.15 \mathrm{E}+02$ \\
\hline HWY240 & $6.29 \mathrm{E}-05$ & $6.29 \mathrm{E}-03$ & $2.59 \mathrm{E}-04$ & $2.59 \mathrm{E}-02$ & $2.22 \mathrm{E}-03$ & $2.22 \mathrm{E}-01$ \\
\hline Offsite & $3.70 \mathrm{E}-05$ & $3.70 \mathrm{E}-03$ & $1.85 \mathrm{E}-04$ & $1.85 \mathrm{E}-02$ & $1.09 \mathrm{E}-03$ & $1.09 \mathrm{E}-01$ \\
\hline
\end{tabular}

For the three conditions analyzed above, the approximate distances at which the EPA Protective Action Guide (PAG) of $0.01 \mathrm{~Sv}(1 \mathrm{rem})$ is exceeded are as follows:

Table 6.30 Seismic Event TRU Release PAG Distances

\begin{tabular}{|c|c|c|c||}
\hline \multicolumn{4}{|c||}{ Approximate Distance at Which PAG (1 rem) Exceeded } \\
\hline \hline Distance & A Stability & D Stability & F Stability \\
\hline \hline Kilometers & $<0.10$ & 0.81 & 1.77 \\
\hline Miles & $<0.06$ & 0.50 & 1.10 \\
\hline
\end{tabular}

The results of this analysis indicate that under severe meteorological conditions this event would meet the criteria for classification as a SITE AREA Emergency, greater than $0.01 \mathrm{~Sv}$ (1 rem) at the facility boundary, but less than $0.01 \mathrm{~Sv}(1 \mathrm{rem})$ at the Site Boundary. 


\section{HNF-SD-PRP-HA-027, Rev. 2}

Table 6.31 Seismic Event LLW Release TEDEs

\begin{tabular}{||c||c|c||c|c||c|c||}
\hline \multirow{2}{*}{ Receptor } & \multicolumn{2}{|c||}{ A Stability Class } & \multicolumn{2}{c||}{ D Stability Class } & \multicolumn{2}{c||}{ F Stability Class } \\
\cline { 2 - 7 } & $\begin{array}{c}\text { TEDE } \\
\text { Sv }\end{array}$ & $\begin{array}{c}\text { TEDE } \\
\text { Rem }\end{array}$ & $\begin{array}{c}\text { TEDE } \\
\text { Sv }\end{array}$ & $\begin{array}{c}\text { TEDE } \\
\text { Rem }\end{array}$ & $\begin{array}{c}\text { TEDE } \\
\text { Sv }\end{array}$ & $\begin{array}{c}\text { TEDE } \\
\text { Rem }\end{array}$ \\
\hline Onsite & $4.41 \mathrm{E}-03$ & $4.41 \mathrm{E}-01$ & $3.42 \mathrm{E}-02$ & $3.42 \mathrm{E}+00$ & $1.45 \mathrm{E}-01$ & $1.45 \mathrm{E}+01$ \\
\hline HWY240 & $7.90 \mathrm{E}-06$ & $7.90 \mathrm{E}-04$ & $5.13 \mathrm{E}-05$ & $5.13 \mathrm{E}-03$ & $2.70 \mathrm{E}-04$ & $2.70 \mathrm{E}-02$ \\
\hline Offsite & $4.61 \mathrm{E}-06$ & $4.61 \mathrm{E}-04$ & $2.30 \mathrm{E}-05$ & $2.30 \mathrm{E}-03$ & $1.38 \mathrm{E}-04$ & $1.38 \mathrm{E}-02$ \\
\hline \hline
\end{tabular}

For the three conditions analyzed above, the approximate distances at which the EPA Protective Action Guide (PAG) of $0.01 \mathrm{~Sv}$ (1 rem) is exceeded are as follows:

Table 6.32 Seismic Event LLW Release PAG Distances

\begin{tabular}{|c|c|c|c|}
\hline \multicolumn{4}{|c||}{ Approximate Distance at Which PAG (1 rem) Exceeded } \\
\hline Distance & A Stability & D Stability & F Stability \\
\hline \hline Kilometers & $<0.10$ & 0.16 & 0.48 \\
\hline Miles & $<0.06$ & 0.10 & 0.30 \\
\hline
\end{tabular}

The results of this analysis indicate that under severe meteorological conditions this event would meet the criteria for classification as a SITE AREA Emergency, greater than $0.01 \mathrm{~Sv}$ (1 rem) at the facility boundary, but less than $0.01 \mathrm{~Sv}(1 \mathrm{rem})$ at the Site Boundary.

\subsubsection{Beyond Design Basis Seismic Event}

In this scenario, a seismic event produces a greater than design basis acceleration of 0.12 $\mathrm{X}$ gravitational acceleration $(0.12 \mathrm{~g})$. In the shipping and receiving area a total of 45 drums are involved. One drum containing the TSR limited amount of 100 grams falls and explodes catching the contents of 35 other fallen and ruptured drums containing 11 grams of TRU each on fire. Nine more drums are ruptured by falling materials. Five drums containing 11 grams each are ruptured in the NDE/NDA area. The contents of one drum containing 11 grams of TRU in the process enclosure spill to the floor of the enclosure and are released through the failed enclosure.

A total of 50 drums are ruptured, 35 of the 50 drums contents burn, and one additional drum explodes.

The release from the 50 ruptured drums is:

$$
(1 \mathrm{E}-6)(50)(11 \text { grams })=5.5 \mathrm{E}-04 \text { grams }
$$




\section{HNF-SD-PRP-HA-027, Rev. 2}

The release from the 35 combusted drums is:

$$
(385-.000385)[(.65)(5 \mathrm{E}-4)+(.35)(6 \mathrm{E}-5)]=0.133 \text { grams }
$$

From the previous section, the release from the exploded drum is 0.107 grams.

The total release from the facility is 0.241 grams.

For LLW, the mechanical release is:

$$
(1 \mathrm{E}-6)^{*}(50)(3120)=0.156 \mathrm{Ci}
$$

The combustion release is:

$$
\left.(109200-.1092) *\left[(.65)^{*}(5 \mathrm{E}-4)+(.35)^{*} 6 \mathrm{E}-5\right)\right]=37.8 \mathrm{Ci} \text {. }
$$

The explosion release is $3.32 \mathrm{Ci}$ from section 6.1.3.

The total release from the facility is $41.3 \mathrm{Ci}$.

Following are the TEDEs for this event.

Table 6.33 Beyond Design Basis Seismic TRU TEDEs

\begin{tabular}{||c||c|c||c|c||c|c||}
\hline \multirow{2}{*}{ Receptor } & \multicolumn{2}{c||}{ A Stability Class } & \multicolumn{2}{c||}{ D Stability Class } & \multicolumn{2}{c||}{ F Stability Class } \\
\cline { 2 - 7 } & $\begin{array}{c}\text { TEDE } \\
\text { Sv }\end{array}$ & $\begin{array}{c}\text { TEDE } \\
\text { Rem }\end{array}$ & $\begin{array}{c}\text { TEDE } \\
\text { Sv }\end{array}$ & $\begin{array}{c}\text { TEDE } \\
\text { Rem }\end{array}$ & $\begin{array}{c}\text { TEDE } \\
\text { Sv }\end{array}$ & $\begin{array}{c}\text { TEDE } \\
\text { Rem }\end{array}$ \\
\hline \hline Onsite & $4.58 \mathrm{E}-02$ & $4.58 \mathrm{E}+00$ & $3.62 \mathrm{E}-01$ & $3.62 \mathrm{E}+01$ & $1.49 \mathrm{E}+00$ & $1.49 \mathrm{E}+02$ \\
\hline HWY240 & $8.19 \mathrm{E}-05$ & $8.19 \mathrm{E}-03$ & $3.37 \mathrm{E}-04$ & $3.37 \mathrm{E}-02$ & $2.89 \mathrm{E}-03$ & $2.89 \mathrm{E}-01$ \\
\hline Offsite & $4.82 \mathrm{E}-05$ & $4.82 \mathrm{E}-03$ & $2.41 \mathrm{E}-04$ & $2.41 \mathrm{E}-02$ & $1.42 \mathrm{E}-03$ & $1.42 \mathrm{E}-01$ \\
\hline
\end{tabular}

For the three conditions analyzed above, the approximate distances at which the EPA Protective Action Guide (PAG) of $0.01 \mathrm{~Sv}$ (1 rem) is exceeded are as follows:

Table 6.34 Beyond Design Basis Seismic TRU PAG Distances

\begin{tabular}{|c|c|c|c|}
\hline \multicolumn{4}{|c||}{ Approximate Distance at Which PAG (1 rem) Exceeded } \\
\hline Distance & A Stability & D Stability & F Stability \\
\hline \hline Kilometers & 0.16 & 0.81 & 2.25 \\
\hline Miles & 0.10 & 0.50 & 1.40 \\
\hline
\end{tabular}




\section{HNF-SD-PRP-HA-027, Rev. 2}

The results of this analysis indicate that under severe meteorological conditions this event would meet the criteria for classification as a SITE AREA Emergency, greater than $0.01 \mathrm{~Sv}$ (1 rem) at the facility boundary, but less than $0.01 \mathrm{~Sv}(1 \mathrm{rem})$ at the Site Boundary.

Table 6.35 Beyond Design Basis Seismic LLW TEDEs

\begin{tabular}{||c||c|c||c|c||c|c||}
\hline \multirow{2}{*}{ Receptor } & \multicolumn{2}{|c||}{ A Stability Class } & \multicolumn{2}{c||}{ D Stability Class } & \multicolumn{2}{c||}{ F Stability Class } \\
\cline { 2 - 7 } & $\begin{array}{c}\text { TEDE } \\
\text { Sv }\end{array}$ & $\begin{array}{c}\text { TEDE } \\
\text { Rem }\end{array}$ & $\begin{array}{c}\text { TEDE } \\
\text { Sv }\end{array}$ & $\begin{array}{c}\text { TEDE } \\
\text { Rem }\end{array}$ & $\begin{array}{c}\text { TEDE } \\
\text { Sv }\end{array}$ & $\begin{array}{c}\text { TEDE } \\
\text { Rem }\end{array}$ \\
\hline \hline Onsite & $2.77 \mathrm{E}-02$ & $2.77 \mathrm{E}+00$ & $2.15 \mathrm{E}-01$ & $2.15 \mathrm{E}+01$ & $9.09 \mathrm{E}-01$ & $9.09 \mathrm{E}+01$ \\
\hline HWY240 & $4.96 \mathrm{E}-05$ & $4.96 \mathrm{E}-03$ & $3.22 \mathrm{E}-04$ & $3.22 \mathrm{E}-02$ & $1.69 \mathrm{E}-03$ & $1.69 \mathrm{E}-01$ \\
\hline Offsite & $2.89 \mathrm{E}-05$ & $2.89 \mathrm{E}-03$ & $1.45 \mathrm{E}-04$ & $1.45 \mathrm{E}-02$ & $8.67 \mathrm{E}-04$ & $8.67 \mathrm{E}-02$ \\
\hline
\end{tabular}

For the three conditions analyzed above, the approximate distances at which the EPA Protective Action Guide (PAG) of $0.01 \mathrm{~Sv}(1 \mathrm{rem})$ is exceeded are as follows:

Table 6.36 Beyond Design Basis Seismic LLW PAG Distances

\begin{tabular}{||c|c|c|c||}
\hline \multicolumn{4}{|c||}{ Approximate Distance at Which PAG (1 rem) Exceeded } \\
\hline Distance & A Stability & D Stability & F Stability \\
\hline \hline Kilometers & 0.16 & 0.64 & 1.61 \\
\hline Miles & 0.10 & 0.40 & 1.00 \\
\hline
\end{tabular}

The results of this analysis indicate that under severe meteorological conditions this event would meet the criteria for classification as a SITE AREA Emergency, greater than $0.01 \mathrm{~Sv}$ (1 rem) at the facility boundary, but less than $0.01 \mathrm{~Sv}(1 \mathrm{rem})$ at the Site Boundary.

\subsubsection{Sabotage Event}

A drum sabotage event was evaluated in the solid waste program sabotage evaluation (FDH 1997). For this event, an ARF of 5E-03 and RF of 3E-01 are assumed based on information from DOE Handbook 3010-YR (DOE 1994). This evaluation assumes an explosion involving 425 grams of TRU. The respirable TRU release totals .638 grams. If the explosion involves LLW, the worst case ${ }^{90} \mathrm{Sr}$ release would be $18.7 \mathrm{Ci}$. 
Following are the TEDEs for this event.

Table 6.37 Sabotage Event TRU TEDEs

\begin{tabular}{||c||c|c||c|c||c|c||}
\hline \multirow{2}{*}{ Receptor } & \multicolumn{2}{c||}{ A Stability Class } & \multicolumn{2}{c||}{ D Stability Class } & \multicolumn{2}{c||}{ F Stability Class } \\
\cline { 2 - 7 } & $\begin{array}{c}\text { TEDE } \\
\text { Sv }\end{array}$ & $\begin{array}{c}\text { TEDE } \\
\text { Rem }\end{array}$ & $\begin{array}{c}\text { TEDE } \\
\text { Sv }\end{array}$ & $\begin{array}{c}\text { TEDE } \\
\text { Rem }\end{array}$ & $\begin{array}{c}\text { TEDE } \\
\text { Sv }\end{array}$ & $\begin{array}{c}\text { TEDE } \\
\text { Rem }\end{array}$ \\
\hline \hline Onsite & $1.21 \mathrm{E}-01$ & $1.21 \mathrm{E}+01$ & $9.57 \mathrm{E}-01$ & $9.57 \mathrm{E}+01$ & $3.96 \mathrm{E}+00$ & $3.96 \mathrm{E}+02$ \\
\hline HWY240 & $2.17 \mathrm{E}-04$ & $2.17 \mathrm{E}-02$ & $8.93 \mathrm{E}-04$ & $8.93 \mathrm{E}-02$ & $7.66 \mathrm{E}-03$ & $7.66 \mathrm{E}-01$ \\
\hline Offsite & $1.28 \mathrm{E}-04$ & $1.28 \mathrm{E}-02$ & $6.38 \mathrm{E}-04$ & $6.38 \mathrm{E}-02$ & $3.76 \mathrm{E}-03$ & $3.76 \mathrm{E}-01$ \\
\hline
\end{tabular}

For the three conditions analyzed above, the approximate distances at which the EPA Protective Action Guide (PAG) of $0.01 \mathrm{~Sv}(1 \mathrm{rem})$ is exceeded are as follows:

Table 6.38 Sabotage Event TRU PAG Distances

\begin{tabular}{|c|c|c|c|}
\hline \multicolumn{4}{|c|}{ Approximate Distance at Which PAG (1 rem) Exceeded } \\
\hline Distance & A Stability & D Stability & F Stability \\
\hline Kilometers & 0.37 & 1.52 & 4.22 \\
\hline Miles & 0.23 & 0.94 & 2.62 \\
\hline
\end{tabular}

The results of this analysis indicate that under severe meteorological conditions this event would meet the criteria for classification as a SITE AREA Emergency, greater than $0.01 \mathrm{~Sv}$ (1 rem) at the Facility Boundary, but less than $0.01 \mathrm{~Sv}(1 \mathrm{rem})$ at the Site Boundary.

Table 6.39 Sabotage Event LLW TEDEs

\begin{tabular}{||c||c|c||c|c||c|c||}
\hline \multirow{2}{*}{ Receptor } & \multicolumn{2}{|c||}{ A Stability Class } & \multicolumn{2}{c||}{ D Stability Class } & \multicolumn{2}{c||}{ F Stability Class } \\
\cline { 2 - 7 } & $\begin{array}{c}\text { TEDE } \\
\text { Sv }\end{array}$ & $\begin{array}{c}\text { TEDE } \\
\text { Rem }\end{array}$ & $\begin{array}{c}\text { TEDE } \\
\text { Sv }\end{array}$ & $\begin{array}{c}\text { TEDE } \\
\text { Rem }\end{array}$ & $\begin{array}{c}\text { TEDE } \\
\text { Sv }\end{array}$ & $\begin{array}{c}\text { TEDE } \\
\text { Rem }\end{array}$ \\
\hline Onsite & $1.25 \mathrm{E}-02$ & $1.25 \mathrm{E}+00$ & $9.72 \mathrm{E}-02$ & $9.72 \mathrm{E}+00$ & $4.11 \mathrm{E}-01$ & $4.11 \mathrm{E}+01$ \\
\hline HWY240 & $2.24 \mathrm{E}-05$ & $2.24 \mathrm{E}-03$ & $1.46 \mathrm{E}-04$ & $1.46 \mathrm{E}-02$ & $7.67 \mathrm{E}-04$ & $7.67 \mathrm{E}-02$ \\
\hline Offsite & $1.31 \mathrm{E}-05$ & $1.31 \mathrm{E}-03$ & $6.55 \mathrm{E}-05$ & $6.55 \mathrm{E}-03$ & $3.93 \mathrm{E}-04$ & $3.93 \mathrm{E}-02$ \\
\hline
\end{tabular}


HNF-SD-PRP-HA-027, Rev. 2

For the three conditions analyzed above, the approximate distances at which the EPA Protective Action Guide (PAG) of $0.01 \mathrm{~Sv}(1 \mathrm{rem})$ is exceeded are as follows:

Table 6.40 Sabotage Event LLW PAG Distances

\begin{tabular}{||c|c|c|c||}
\hline \multicolumn{4}{|c||}{ Approximate Distance at Which PAG (1 rem) Exceeded } \\
\hline \hline Distance & A Stability & D Stability & F Stability \\
\hline Kilometers & 0.12 & 0.39 & 1.00 \\
\hline Miles & 0.08 & 0.24 & 0.62 \\
\hline \hline
\end{tabular}

The results of this analysis indicate that under severe meteorological conditions this event would meet the criteria for classification as a SITE AREA Emergency, greater than $0.01 \mathrm{~Sv}$ (1 rem) at the facility boundary, but less than $0.01 \mathrm{~Sv}(1 \mathrm{rem})$ at the Site Boundary.

\subsection{SUGGESTED EMERGENCY ACTION LEVELS AND EVENT CLASSIFICATIONS}

\subsection{Toxic Chemical Emergencies}

No toxic chemicals exceeding the screening thresholds were identified at WRAP.

\subsection{Radiological Emergencies}

The confinement systems provided in the WRAP design consist of the process enclosures and the ventilation systems (primary barrier) and the building structure enclosing the process area and associated ventilation system (secondary barrier). In areas other than the enclosure lines, waste containers will not be opened, but will be handled or stored. In these areas, the containers themselves, including any required liners, provide confinement.

The following miscellaneous systems are designed to help detect the failure of containment systems or equipment.

- Radiation monitoring systems display locally and/or remotely.

- Safety alarms, such as fire and radiation, are monitored and displayed in the control area on a hard-wired annunciator panel and on the control system. Failure of one alarm system does not prevent the alarm from being displayed at the other. Fire alarms also are monitored in the 200 Area Fire Station.

- Continuous air monitors (CAMs) are located in the exhaust stack. 


\section{HNF-SD-PRP-HA-027, Rev. 2}

- Radiation monitoring instrumentation is on an uninterruptible power supply and independently returns to normal operation following switching transients.

- Trouble alarms are used to indicate the proper operation of equipment. These are fail open alarms that alarm on loss of signal; therefore, a positive state-of-health signal must be received from the device to confirm its operation. These signals are separate from the safety alarm signals.

The area radiation monitoring system warns facility operations of unexpected increases in area radiation levels. The air sampling and monitoring program warns personnel of the unexpected release of airborne radioactive materials, provides data regarding potential personnel exposures and the effectiveness of containment systems. CAMs sample and monitor the air and are designed to provide early warning of a significant release of radioactive material. CAMs are installed in WRAP areas where an individual is likely to be exposed to a concentration of airborne radioactivity exceeding one DAC as specified in 10 CFR 835, Appendix A, or where there is a need to alert personnel to unexpected increases in airborne radioactivity levels because of equipment or confinement failure.

Direct readings from installed facility radiation monitoring equipment should be incorporated into facility specific EALs and the resulting classification procedures.

\subsubsection{Loss of Confinement}

Section 6.1.1 analyzes an event that involves a spill from waste drums of a SWB in the NDE/NDA or shipping and receiving area with the doors open and a direct path to the environment. The consequences of this event would also apply if it were to occur outside of the building (e.g., loading dock, transport vehicle, etc.).

The results indicate that for drums or a SWB containing TRU the event should be classified as an ALERT. If the drums contain LLW then the consequences would not meet the criteria for classification as an Operational Emergency.

Since it may not be immediately apparent whether or not the drums involved in this type of event contain TRU or LLW, any event involving the release of the contents of two or more 208-liter (55-gallon) containers of one SWB should be classified as an ALERT.

Potential Event Indicators. Indicators for this type of event which could be used to produce facility specific EALs include:

- Personnel observations

- CAM alarms

- $\quad$ Results of radiological field surveys. 


\section{HNF-SD-PRP-HA-027, Rev. 2}

\section{Sample EAL statement:}

Any event that results in the release of the contents of two or more 208-l containers or the contents of one SWB AND the event occurs outside the facility OR there is a direct unfiltered path to the environment (i.e., open door)should be declared an ALERT.

\subsubsection{Facility Fire}

Three fire scenarios were analyzed in section 6.0, drum spill and fire (6.1.2), drum explosion and fire (6.1.3 and 6.1.6), and fire in process enclosure (6.1.4). The results indicated that, assuming a direct release path to the environment (e.g., open door, failed filter, etc.), the resulting event classification should be SITE AREA Emergency, regardless of whether the contents of the drums are TRU or MFP.

Potential Event Indicators. Indicators for this type of event which could be used to produce facility specific EALs include:

- Personnel observations

- Fire alarm

- $\quad$ area CAM alarms

- $\quad$ stack CAM alarm

- $\quad$ Results of radiological field surveys.

\section{Sample EAL statements:}

Any fire within the facility that threatens waste storage containers or storage locations that burns uncontrolled for longer then 15 minutes AND requires Hanford Fire Department (HFD) response should be classified as an ALERT.

Any major facility fire involving waste storage containers or waste storage locations that is not able to be controlled within one hour of the arrival of the HFD should be declared a SITE AREA EMERGENCY.

Any fire involving the contents of one or more waste containers outside of the facility (e.g., loading dock, transport vehicle, etc.) should be declared a SITE AREA EMERGENCY.

Any fire inside the facility involving the contents of one or more waste containers where there is a direct unfiltered path to the environment (i.e., open door, failed filter system) AND local and/or stack CAM alarms have been received should be declared a SITE AREA EMERGENCY. 


\section{HNF-SD-PRP-HA-027, Rev. 2}

\subsubsection{Explosion of Waste Container}

Section 6.0 examines scenarios involving the explosion of waste containers in the $\mathrm{NDE} / \mathrm{NDA}$, receiving and shipping (6.1.3), and process enclosure areas (6.1.6 and 6.1.7). In each case where a direct release path to the environment was assumed, the results indicate that the event should be declared a SITE AREA Emergency.

Potential Event Indicators. Indicators for this type of event which could be used to produce facility specific EALs include:

- Personnel observations

- $\quad$ Fire alarm

- Loss of negative pressure in confinement areas

- $\quad$ area CAM alarms

- $\quad$ stack CAM alarm

- Results of radiological field surveys.

Sample EAL statements:

Any explosion outside the facility involving one or more waste containers should be declared a SITE AREA EMERGENCY.

Any explosion within the facility involving one or more waste containers where there is a direct unfiltered release path to the environment (i.e., open door, failed filter system and/or confinement boundary) $A N D$ local and/or stack CAM alarms have been received should be declared a SITE AREA EMERGENCY.

\subsubsection{External Events}

The following events were not specifically analyzed in section 6.0. This accident type considers events which are man made but originate external to the WRAP facility, that could have an adverse effect on facility safety. Events discussed include loss of utilities, aircraft accidents and accidents at nearby facilities.

Loss of Utilities. Normal power for WRAP is derived from an outdoor substation located at the northwest corner of the building. The transformers feed two $480-\mathrm{V}$ switchgear assemblies. Both transformers feed a common bus with a normally open manual tiebreaker for load separation and/or reduced load sharing. All transformer feeds are to the main switchgear assembly and all electrical equipment in WRAP derives its power from this switchgear. There is no provision for emergency or standby power but an uninterruptible power supply is available for selected loads, as described in the following section. 


\section{HNF-SD-PRP-HA-027, Rev. 2}

WRAP is not required to operate under all conditions. In the event of a total loss of power, the uninterruptible power supply system supplies battery power for approximately 55 minutes to operate alarms until personnel are evacuated; provide emergency instructions over the communication system; preserve PCS information; and operate continuous air stack, and radiation monitors. All lifting equipment is designed to maintain loads on loss of power. A shutdown of this nature would not preserve the ventilation zone confinements with negative pressures in process enclosures and process rooms. However, the HVAC dampers and valves are designed to fail in their safe state on loss of power. The safe state is the state in which contamination is contained within its enclosure(s). The uninterruptible power supply can accept a plug-in portable generator to maintain selected loads indefinitely.

No consequences resulting in the loss of control of hazardous materials are expected due to the disruption of utility services to the WRAP Facility.

Adjacent Facilities. The nearest hazardous material facility to WRAP is the Plutonium Finishing Plant (PFP), which is located approximately 800 meters southeast of WRAP. There are other facilities in the 200 West Area, such as tank farms, that contain radioactive or toxic materials. There are no potential accidents identified at these facilities that could significantly physically damage the WRAP Facility. Radiological or toxic releases from other facilities could affect facility personnel. Hanford Emergency Response procedures will result in site alarms being activated in case of an accident at other facilities.

Due to the proximity of WRAP to other hazardous material facilities within the 200 West Area, any event involving the actual or potential release of hazardous material could have serious health and safety implications for personnel at WRAP. Therefore, it is suggested that the declaration of an Operational Emergency and initiation of protective actions at any facility within the 200 West Area should be closely coordinated with the WRAP Building Emergency Director.

Aircraft Crash. There are a range of possible releases from an aircraft crash. A light aircraft crash near the facility may not release any material whereas a direct hit from a commercial jet liner could cause extensive damage to the facility and a release of facility contamination.

The airspace over the 200 West Area is declared a no-flight zone for local, low-level flights. Analyses carried out for other site facilities indicate that an aircraft crash into the WRAP facility is an extremely unlikely event (Mulestein, 1994). However, such a crash could result in impacts to the radioactive materials present in the facility. The consequences of such an impact could be similar to the beyond design basis earthquake analyzed in section 6.1 .9 or the sabotage event analyzed in section 6.1.10. The consequences of these accidents have been analyzed above. 


\section{HNF-SD-PRP-HA-027, Rev. 2}

The consequences of a light private, commercial or military aircraft crash have been bounded by scenarios addressed above. Based on the consequences from the worst-case, it is recommended that any aircraft accident at WRAP that results in damage breaching the building confinement structures AND involves a major structural fire be classified as a SITE AREA EMERGENCY.

Potential Event Indicators. Indicators for these types of events which could be used to produce facility specific Emergency Action Levels (EALs) include:

- Personnel observations

- $\quad$ Notification from adjacent facility

- Confirmed structural damage to facility confinement. Which may be indicated by personnel observations, ventilation system differential pressure monitors, activation of exhaust and supply interlocks, and failure of ventilation system components.

- $\quad$ Area or stack CAM alarms

- Results of radiological field surveys.

Sample EAL statements:

Any aircraft crash near the WRAP facility should be classified as an ALERT.

Any aircraft crash which causes major structural damage (i.e., loss of confinement for stored or processed waste) AND results in a structural fire should be classified as a SITE AREA Emergency.

\subsubsection{Natural Phenomena}

Two seismic events were analyzed in sections 6.1 .8 and 6.1.9. Events also considered in this section include high winds/tornadoes, flooding and ash roof loading.

Seismic Events. Two earthquake scenarios were analyzed for WRAP. The first is a design basis earthquake with a peak ground acceleration of $0.12 \mathrm{~g}$ and the second is a beyond design basis earthquake with a ground acceleration greater then $0.20 \mathrm{~g}$. WRAP is designed to withstand $0.12 \mathrm{~g}$ horizontal acceleration. It is unlikely that the exact magnitude of an earthquake will be immediately known, therefore based on the worst case analysis, any earthquake which results in damage to facility confinement structures should be classified as a SITE AREA Emergency.

High Winds/Tornados. Some damage is expected if high winds or a tornado strike the WRAP Facility, such as damage to the external structures, upset of the ventilation system or damage to the exhaust stack. Release of hazardous materials from these type of events is expected to be minor and the consequences are bounded by the analyses of other scenarios. 


\section{HNF-SD-PRP-HA-027, Rev. 2}

Extreme winds and the associated wind pressures on WRAP constitute the major severe weather hazard to the facility. The maximum recorded peak wind gust at 15.2 meters above ground level is 129 kilometers per hour, which occurred in January 1972 as recorded by the Hanford Meteorological Station (HMS). The HMS is about 4.8 kilometers east of the WRAP site. Uniform design and evaluation guidelines for protection against extreme wind hazards at Hanford Site facilities have been developed based on these wind data and are used to determine the design criteria for structures, systems, and components (SSC). Aboveground SSCs are designed to withstand wind speeds of 112 kilometers per hour (DOE Order 6430.1A), including the WRAP Building and stack.

Tornados are very rare in the vicinity of the Hanford Site. The DOE-RL no longer requires design criteria to be established for tornados for nonreactor facilities on the Hanford Site (DOE-STD-1020-94).

To maintain consistency with EALs in use at other facilities it is suggested that an ALERT should be declared if sustained winds exceed $4.0 \mathrm{E}+1 \mathrm{~m} / \mathrm{s}(90 \mathrm{mph})$ and resulting damage to the facility is observed. And a SITE AREA Emergency should be declared if a tornado strikes the facility AND causes damage to facility confinement structures.

Flooding. Three scenarios for possible flooding on the Hanford Site are dam failure, river blockage, and intense precipitation.

The maximum postulated flood scenario results from a hypothetical 50 percent breach of Grand Coulee Dam on the Columbia River, upstream from the Hanford Site. This scenario is calculated to result in an inundation of the Hanford Site with flood waters to an elevation of about 140 meters above mean sea level. Because the WRAP site is at an elevation of about 213 meters above mean sea level, WRAP would remain about 73 meters above flood level for this scenario. The potential for massive landslides along the Columbia River is judged to be bounded by the 50 percent breach of Grand Coulee Dam case.

The location of WRAP on the 200 Area plateau, in addition to the grading and drainage features that are provided, ensures that precipitation, even from a downpour as severe as 30 centimeters in 24 hours, would infiltrate the ground or drain off toward the Columbia River without significant flooding. Controls preclude adverse impacts from less severe local precipitation run-on and run-off. WRAP is not sited in a wetlands or coastal high-hazard area.

Ash/Snow Roof Loading. WRAP structures are designed to withstand snow loading in accordance with Section 7 of American National Standards Institute 158.1, using the following criteria:

- Ground snow load - 73 kilograms per square meter

- Minimum roof load - 98 kilograms per square meter. 


\section{HNF-SD-PRP-HA-027, Rev. 2}

Table 2.1 indicates the estimated ash depth (and equivalent roof loadings) deposited at the Hanford Site from past volcanic eruptions in the region. As seen from the estimated roof loadings, the WRAP roof is expected to withstand all but the most severe ash loading.

The consequences of a roof collapse due to snow/ash loading would be similar to a seismic event resulting in building damage. The consequences from seismic events were analyzed in sections 6.1.8 and 6.1.9. The results indicate that this type of event should be classified as a SITE AREA Emergency.

Potential Event Indicators. Indicators for these types of events which could be used to produce facility specific Emergency Action Levels (EALs) include:

- Personnel observations

- Indications from local seismic stations

- Local or site meteorological system

- Results from routine radiological surveys.

- $\quad$ And confirmed structural damage to facility confinement. Which may be indicated by personnel observations, ventilation system differential pressure monitors, activation of exhaust and supply interlocks, area and/or stack CAM alarms, and failure of ventilation system components.

\section{Sample EAL Statements:}

Any earthquake which results in damage to facility confinement structures AND local and/or stack CAM alarms have been received should be classified as a SITE AREA Emergency.

Sustained winds in excess of $4.0 E+1 \mathrm{~m} / \mathrm{s}(90 \mathrm{mph})$ AND observed damage to facility confinement structures should be declared an ALERT.

A tornado strike to the WRAP Facility AND damage to facility confinement structures AND local and/or stack CAM alarms should be classified as a SITE AREA Emergency.

Severe ash/snow loading AND observed roof collapse AND local and/or stack CAM alarms should be classified as a SITE AREA Emergency

\subsubsection{Safeguards and Security}

Malevolent acts involving explosive devices, sabotage, and hostage/armed intruder could result in degradation of facility safety or loss of control over hazardous materials which would warrant the declaration of an event classification.

Explosive Device. An actual detonation of an explosive device in an area of the facility containing radioactive materials could result in their release to the environment. The consequences of this type of an event would be similar to or be bounded by the beyond design basis earthquake (6.1.9) or sabotage scenario (6.1.10). 


\section{HNF-SD-PRP-HA-027, Rev. 2}

Based on the results of the analysis of the sabotage event in section 6.1.10, it is suggested that the discovery, detonation or credible threatened detonation of an explosive device in any waste storage or processing area of WRAP be classified as a SITE AREA Emergency.

Sabotage Scenario. Acts of sabotage could result in the release of hazardous material to the environment. The most serious consequences are bounded by the use of explosive devices above. Therefore, based on bounding events for damage to facility confinement structures, confirmed physical damage to the confinement structures of WRAP from sabotage, which causes an actual or potential release of hazardous materials to the environment, should be classified as a SITE AREA Emergency.

Hostage Situation/Armed Intruder. A confirmed hostage situation, armed intruder, credible security threat, or ongoing security compromise involving physical attack on the WRAP facility that causes the actual or potential release of hazardous materials should be classified as a SITE AREA Emergency. Some examples of these types of events are as follows:

- $\quad$ An armed assault directed at an individual employee, at gaining access to valuable property or classified material, or at causing damage to facility property. The motivation for and objectives of such an assault may not be know until long after the fact.

- Kidnaping of a Site employee or family member or the taking of hostages undertaken to extort money, materials, or concessions from the DOE, contractor or individual employee. The DOE, contractor, or employee may come under great pressure to meet the perpetrator's demands, some of which may have safety, health or environmental implications.

- $\quad$ Any damage or destruction sufficient to expose classified information to unauthorized disclosure.

\section{Example EAL Statements:}

Discovery, detonation or credible threatened detonation of an explosive device in any waste storage or processing area should be classified as a SITE AREA Emergency.

Confirmed physical damage to confinement structures from sabotage, which causes an actual or potential release of hazardous materials to the environment, should be classified as a SITE AREA Emergency.

Confirmed hostage situation, armed intruder, credible security threat, or ongoing security compromise that causes the actual or potential release of hazardous materials should be classified as a SITE AREA Emergency. 


\section{HNF-SD-PRP-HA-027, Rev. 2}

\subsubsection{Event Classification Based on Radiological Field Measurements}

Releases due to loss of facility confinement are often difficult to quantify because of the uncertainty regarding source terms, release conditions, and initiating event(s). Two additional methods, based on field measurement, which could be used for event classification include, ground contamination surveys downwind from the facility and measurements of activity collected on the stack ISEMS CAM or Record Sampler filter papers.

\subsubsection{Ground Contamination Surveys.}

The method is to determine the ground contamination levels at a receptor point associated with the release criteria. This is done by determining the chi/Q value at a receptor point and multiplying it by the source term and a deposition velocity of 0.001 meters/second. This will provide a value representing "general" ground contamination in curies per square meter.

The chi/ $\mathrm{Q}$ values under worst case weather conditions $(1-\mathrm{m} / \mathrm{sec} \mathrm{F}$ stability) at the facility boundary (100 meter) receptor point is $3.06 \mathrm{E}-02 \mathrm{sec} / \mathrm{m}^{3}$ and at the nearest site boundary receptor $(8.7 \mathrm{~km})$ is $2.92 \mathrm{E}-05 \mathrm{sec} / \mathrm{m}^{3}$ (Scherpelz, 1991). For these conditions, the following release quantities will meet the event classification criteria.

Table 7.1 Release Quantities that Meet Classification Criteria

\begin{tabular}{||c|c|c|c||}
\hline & ALERT & $\begin{array}{c}\text { SITE AREA } \\
\text { EMERGENCY }\end{array}$ & $\begin{array}{c}\text { GENERAL } \\
\text { EMERGENCY }\end{array}$ \\
\hline \hline TRU (grams) & $1.60 \mathrm{E}-04$ & $1.60 \mathrm{E}-03$ & $1.70 \mathrm{E}+00$ \\
\hline MFP (Ci) & $4.55 \mathrm{E}-02$ & $4.55 \mathrm{E}-01$ & $4.76 \mathrm{E}+02$ \\
\hline
\end{tabular}

Using the information contained in Table 4.1 about the $12 \%$ Nominal Pu-240 isotopic mixture assumed in this analysis the gram quantities of TRU listed above were converted to total curies as follows; $1.60 \mathrm{E}-04 \mathrm{gm}=2.48 \mathrm{E}-05 \mathrm{Ci} ; 1.60 \mathrm{E}-03 \mathrm{gm}=2.48 \mathrm{E}-04 \mathrm{Ci}$; and $1.7 \mathrm{E}+00 \mathrm{gm}=$ 2.64E-01 Ci.

Using the assumptions above the ground deposition of TRU material at a distance of 100 $m$ which would indicate the need to classify an event as an ALERT is:

$(2.48 \mathrm{E}-05 \mathrm{Ci})(2.22 \mathrm{E}+12 \mathrm{dpm} / \mathrm{Ci})\left(3.06 \mathrm{E}-02 \mathrm{sec} / \mathrm{m}^{3}\right)(.001 \mathrm{~m} / \mathrm{sec})$ or

$$
1.68 \mathrm{E}+03 \mathrm{dpm} / \mathrm{m}^{2} \text { which equals }\left(1.68 \mathrm{E}-01 \mathrm{dpm} / \mathrm{cm}^{2}\right)
$$

Assuming a probe area of $50 \mathrm{~cm}^{2}$ for a PAM and a probe efficiency of $14 \%$ (HNF-PRO633 ), a general surface contamination reading of $1.2 \mathrm{cpm}$ or greater would be expected. Using the same methodology the surface contamination reading at $100 \mathrm{~m}$ that would indicate the need to classify an event as a SITE AREA EMERGENCY is $>12 \mathrm{cpm}$ and as a GENERAL 


\section{HNF-SD-PRP-HA-027, Rev. 2}

EMERGENCY is $>1.26 \mathrm{E}+04 \mathrm{cpm}$. Note: MDA for a PAM probe is $45 \mathrm{dpm}(6.3 \mathrm{cpm})$ for a 20 second count. Therefore the threshold for ALERT is below the lower limit of detection for this type of instrument.

A similar calculation can be performed for the LLW releases. In this case, $4.55 \mathrm{E}-02 \mathrm{Ci}$ of MFP needs to be released as respirable material to meet the ALERT criteria. Since this value represents primarily $\mathrm{Sr}^{90}$, it will be multiplied by 2 to account for the equal activity of $\mathrm{Y}^{90}$ present. Using the assumptions above the ground deposition of TRU material at a distance of 100 $m$ which would indicate the need to classify an event as an ALERT is:

(2) $(4.55 \mathrm{E}-02 \mathrm{Ci})(2.22 \mathrm{E}+12 \mathrm{dpm} / \mathrm{Ci})\left(3.06 \mathrm{E}-02 \mathrm{sec} / \mathrm{m}^{3}\right)(.001 \mathrm{~m} / \mathrm{sec})$ or $6.18 \mathrm{E}+06 \mathrm{dpm} / \mathrm{m}^{2}$ which equals $\left(618 \mathrm{dpm} / \mathrm{cm}^{2}\right)$

Assuming a probe area of $15 \mathrm{~cm}^{2}$ for a GM with a P-11 probe and a $10 \%$ counting efficiency, a general surface contamination reading at $100 \mathrm{~m}$ of $9.27 \mathrm{E}+02 \mathrm{cpm}$ or more would be expected. In a similar fashion, release requiring classification as a SITE AREA EMERGENCY would be indicated by readings at $100 \mathrm{~m}$ of $9.27 \mathrm{E}+03 \mathrm{cpm}$ or more. Contamination which would indicate a General Emergency condition (e.g., $9.70 \mathrm{E}+06 \mathrm{cpm}$ ) would result in readings beyond the upper range of this instrument (i.e., $1.0 \mathrm{E}+05 \mathrm{cpm}$ ).

\subsubsection{CAM Filter Paper Activity.}

The method employed is to determine the activity that would be measured by hand held instruments on the ISEMS CAM or Record Sampler filter papers if quantities of TRU or MFP were released to the environment through the stack which exceed the classification thresholds.

The following assumptions* are made:

- Stack flowrate $16,500 \mathrm{cfm}$

- ISEMS sample flow rate $20 \mathrm{cfm}$

- Record sampler flow rate $2 \mathrm{cfm}$

- ISEMS filter area $314 \mathrm{~cm}^{2}$

- Record sampler filter area $47 \mathrm{~cm}^{2}$

- P-11 probe area $15 \mathrm{~cm}^{2}$

- PAM probe area $50 \mathrm{~cm}^{2}$

- P-11 probe efficiency $10 \%$

- PAM probe efficiency $14 \%$

- MDA for P-11 is $600 \mathrm{dpm}$ with background of $<150 \mathrm{cpm}$

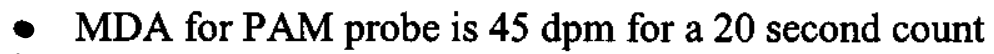
(See HNF-PRO-632 \& 633) 


\section{HNF-SD-PRP-HA-027, Rev. 2}

\section{$\underline{\text { ISEMS CAM Filter }}$}

For a release of TRU through the stack which should be classified as an ALERT the alpha activity seen on the ISEMS CAM filter paper would be:

$(2.48 \mathrm{E}-05 \mathrm{Ci})(2.22 \mathrm{E}+12 \mathrm{dpm} / \mathrm{Ci})(20 \mathrm{cfm} / 16,500 \mathrm{cfm})=6.67 \mathrm{E}+04 \mathrm{dpm} / \mathrm{filter}$

$(6.67 \mathrm{E}+04 \mathrm{dpm} / \mathrm{filter})\left(\right.$ filter $\left./ 314 \mathrm{~cm}^{2}\right)\left(50 \mathrm{~cm}^{2} / \mathrm{PAM}\right.$ probe $)(.14 \mathrm{cpm} / \mathrm{dpm})=1.49 \mathrm{E}+03 \mathrm{cpm} / \mathrm{PAM}$ probe

In a similar fashion, a release requiring classification as a SITE AREA EMERGENCY would be indicated by readings on the ISEMS CAM filter with a PAM of $1.49 \mathrm{E}+04 \mathrm{cpm}$ or more and $1.58 \mathrm{E}+07 \mathrm{cpm}$ or more for classification of a GENERAL EMERGENCY. Note: The threshold for GENERAL EMERGENCY is above the upper range of this instrument (i.e., $1 \mathrm{E}+05)$.

A similar calculation can be performed for the LLW releases. In this case, $4.55 \mathrm{E}-02 \mathrm{Ci}$ of MFP needs to be released as respirable material to meet the ALERT criteria.

For a release of MFP through the stack which should be classified as an ALERT the activity seen on the ISEMS CAM filter paper would be:

(2) $(4.55 \mathrm{E}-02 \mathrm{Ci})(2.22 \mathrm{E}+12 \mathrm{dpm} / \mathrm{Ci})(20 \mathrm{cfm} / 16,500 \mathrm{cfm})=2.44 \mathrm{E}+08 \mathrm{dpm} /$ filter

$(2.44 \mathrm{E}+08 \mathrm{dpm} / \mathrm{filter})\left(\mathrm{filter} / 314 \mathrm{~cm}^{2}\right)\left(15 \mathrm{~cm}^{2} / \mathrm{P}-11 \mathrm{probe}\right)(.10 \mathrm{cpm} / \mathrm{dpm})$

$=1.17 \mathrm{E}+06 \mathrm{cpm} / \mathrm{P}-11$ probe

Activity levels which would indicate an ALERT or higher condition would result in readings beyond the upper range of a GM with a $\mathrm{P}-11$ probe(i.e., $1.0 \mathrm{E}+05 \mathrm{cpm})$.

\section{Record Sampler Filter}

For a release of TRU through the stack which should be classified as an ALERT the alpha activity seen on the Record Sampler filter paper would be:

$(2.48 \mathrm{E}-05 \mathrm{Ci})(2.22 \mathrm{E}+12 \mathrm{dpm} / \mathrm{Ci})(2 \mathrm{cfm} / 16,500 \mathrm{cfm})=6.67 \mathrm{E}+03 \mathrm{dpm} /$ filter

The probe area is slightly larger then the filter, therefore the probe will see all the activity on the surface of the filter.

$(6.67 \mathrm{E}+03 \mathrm{dpm} / \mathrm{filter})(.14 \mathrm{cpm} / \mathrm{dpm})=9.34 \mathrm{E}+02 \mathrm{cpm} / \mathrm{PAM}$ probe

In a similar fashion, a release requiring classification as a SITE AREA EMERGENCY would be indicated by readings on the Record Sampler filter with a PAM of $9.34 \mathrm{E}+03 \mathrm{cpm}$ or more and $9.95 \mathrm{E}+06 \mathrm{cpm}$ or more for classification of a GENERAL EMERGENCY. Note: The 


\section{HNF-SD-PRP-HA-027, Rev. 2}

GENERAL EMERGENCY threshold is above the upper limit for this instrument.

A similar calculation can be performed for the $\mathrm{LLW}$ releases. In this case, $4.55 \mathrm{E}-02 \mathrm{Ci}$ of MFP needs to be released as respirable material to meet the ALERT criteria.

For a release of MFP through the stack which should be classified as an ALERT the activity seen on the Record Sampler filter paper would be:

(2) $(4.55 \mathrm{E}-02 \mathrm{Ci})(2.22 \mathrm{E}+12 \mathrm{dpm} / \mathrm{Ci})(2 \mathrm{cfm} / 16,500 \mathrm{cfm})=2.44 \mathrm{E}+07 \mathrm{dpm} /$ filter

$(2.44 \mathrm{E}+07 \mathrm{dpm} /$ filter $)\left(\right.$ filter $\left./ 47 \mathrm{~cm}^{2}\right)\left(15 \mathrm{~cm}^{2} / \mathrm{P}-11 \mathrm{probe}\right)(.10 \mathrm{cpm} / \mathrm{dpm})=7.78 \mathrm{E}+05 \mathrm{cpm} / \mathrm{P}-11$ probe

Activity levels which would indicate an ALERT or higher condition would result in readings beyond the upper range of a GM with a $\mathrm{P}-11$ probe(i.e., $1.0 \mathrm{E}+05 \mathrm{cpm}$ ).

\section{Sample EAL Statements:}

Any surface contamination measurement taken $\sim 100 \mathrm{~m}$ downwind $>9.27 E+02 \mathrm{cpm}$ but $<$ 9.27E+03 with a P-11 should be classified as an ALERT

Any surface contamination measurement taken $\sim 100 \mathrm{~m}$ downwind $>9.27 E+03 \mathrm{cpm}$ with a $P-11$ OR $>12$ cpm with a PAM should be classified as a SITE AREA EMERGENCY

Any surface contamination measurement taken on the ISEMS CAM filter paper $>1.49 E+03 \mathrm{cpm}$ but $<1.49 E+04$ OR on the Record Sampler filter $>9.34 E+02 \mathrm{cpm}$ but $<9.34 E+03$ with a PAM should be classified as an ALERT

Any surface contamination measurement taken on the ISEMS CAM filter paper $>1.49 E+04 \mathrm{cpm}$ $O R$ on the Record Sampler filter $>9.34 E+03 \mathrm{cpm}$ with a PAM should be classified as a SITE AREA EMERGENCY 


\subsection{THE EMERGENCY PLANNING ZONE}

The Emergency Planning Zone (EPZ) is an area within which special planning and preparedness efforts are warranted to mitigate the consequences of a severe accident. DOE Orders endorses the EPZ concept and requires that the choice of an EPZ for each facility be based on an objective analyses of the hazards associated with the facility. The DOE Emergency Management Guide recommends developing a composite EPZ@ for a group of facilities located in close proximity to one another.

Using the results of facility hazards assessments and the method outlined in the EMG, a composite EPZ for the 200 East area facilities has previously been established and documented in the Hanford Site Emergency Plan. The EPZ includes the area within a 10 mile radius of the geographic center of the 200 West Area. Ten miles, the maximum EPZ radius recommended by the EMG, was based on the combined weight of analysis results for postulated events associated with underground high level waste storage tank (Tank Farms) operations. The EPZ and its bases were reviewed against the results of this hazards assessment. It is concluded that the existing $\mathrm{EPZ}$ is still adequate and that no changes to the EPZ are warranted on the basis of this hazards assessment.

The following table contains the dose (TEDE) at the EPZ boundary, under severe meteorological conditions, for the scenarios analyzed in section 6.0 of this report. WRAP is less then two miles from the geographic center of the 200 East Area, so a conservative distance of 8 miles $(12.9 \mathrm{~km})$ to the nearest $\mathrm{EPZ}$ boundary was used.

Table 8.1 Dose at EPZ Boundary

\begin{tabular}{||l|c|c|c||}
\hline \multicolumn{1}{|c|}{ Accident Scenario } & Section & TRU Dose (rem) & $\begin{array}{c}\text { MFP Dose } \\
\text { (rem) }\end{array}$ \\
\hline NDE/NDA or Shipping and Receiving Area Spill & 6.1 .1 & $1.05 \mathrm{E}-04$ & $8.11 \mathrm{E}-06$ \\
\hline $\begin{array}{l}\text { NDE/NDA or Shipping and Receiving Area Spill } \\
\text { w/Fire }\end{array}$ & 6.1 .2 & $3.63 \mathrm{E}-02$ & $2.82 \mathrm{E}-03$ \\
\hline $\begin{array}{l}\text { NDE/NDA or Shipping and Receiving Area Drum } \\
\text { Explosion }\end{array}$ & 6.1 .3 & $8.09 \mathrm{E}-02$ & $4.32 \mathrm{E}-03$ \\
\hline Fire in Process Enclosures w/Filter Failure & 6.1 .4 & $2.66 \mathrm{E}-02$ & $1.42 \mathrm{E}-03$ \\
\hline Drum Fire in TRU Process Enclosure w/Filter Intact & 6.1 .5 & N/A & N/A \\
\hline $\begin{array}{l}\text { Drum Fire in TRU Process Enclosure w/Filter } \\
\text { Failure }\end{array}$ & 6.1 .6 & $5.02 \mathrm{E}-01$ & $2.69 \mathrm{E}-02$ \\
\hline $\begin{array}{l}\text { Drum Explosion in Process Enclosure w/Filter } \\
\text { Intact }\end{array}$ & 6.1 .7 & N/A & N/A \\
\hline Seismic Event & 6.1 .8 & $7.03 \mathrm{E}-02$ & $8.55 \mathrm{E}-03$ \\
\hline Beyond Design Basis Seismic Event & 6.1 .9 & $9.16 \mathrm{E}-02$ & $5.37 \mathrm{E}-02$ \\
\hline Sabotage Event & 6.1 .10 & $2.42 \mathrm{E}-01$ & $2.43 \mathrm{E}-02$ \\
\hline
\end{tabular}


HNF-SD-PRP-HA-027, Rev. 2

\subsection{MAINTENANCE AND REVIEW OF THIS HAZARDS ASSESSMENT}

WMH is responsible for ensuring that this Hazards Assessment is reviewed annually and maintained current. The review requirement is specified in Hanford Emergency Response Plan, DOE/RL-94-02, section 4.0.

\subsection{REFERENCES}

Campbell, L. R., 1996, Columbia River Flood Emergency Preparedness Hazards Assessment, WHC-SD-PDP-HA-029 Rev. 0, Westinghouse Hanford Co., Richland Washington, July, 1996.

Cushing, C. E., 1992, Hanford Site National Environmental Policy Act (NEPA)

Characterization, PNL-6415 Rev. 5, Pacific Northwest Laboratory, Richland, Washington.

DOE, 1986, Environmental Assessment, Reference Repository Location, Hanford Site, Washington, DOE/RW-0070, U.S. Department of Energy, Washington, D.C.

DOE, 1987, Environmental Impact Statement, Disposal of Hanford High-Level and Transuranic and Tank Wastes, Hanford Site, Richland, Washington. DOE/EIS-0113, Vol. I-III, U.S. Department of Energy, Washington, D.C.

DOE, 1992, "Hazards Assessment," DOE Emergency Management Guide, U.S. Department of Energy, Washington, D.C.

DOE, 1994, Airborne Release Fractions/Rates and Respirable Fractions for NonReactor Nuclear Facilities, DOE-HDBK-3010-94, U.S. Department of Energy, Washington, D.C.

DOE, 1995, Comprehensive Emergency Management System, DOE Order O 151.1, as amended, U.S. Department of Energy, Washington, D.C. 20585.

DOE, 1997, Emergency Management Guide, Volume II, Hazards Surveys and Hazards Assessments, August 21, 1997, U.S. Department of Energy, Washington, D.C. 20585.

ERDA, 1976 Evaluation of Impact of Potential Flooding Criteria on the Hanford Project, RLO76-4, U.S. Energy Research and Development Administration, Richland, Washington.

FDH, 1997 Solid Waste Program Vulnerability/Risk Analysis (As of February 1997), HNF9600048-REV1, Fluor Daniel Hanford, Richland Washington, May, 1997.

HNF-PRO-632, Portable Alpha Meter (PAM) 


\section{HNF-SD-PRP-HA-027, Rev. 2}

HNF-PRO-633, GM Portable Survey Instrument

Homann, 1988, EPI code(TM), Homann Associates, Inc., Copyright 1988. (The latest version owned by WHC Emergency Preparedness is Rev. 4.1.).

WMH, 1998, Waste Receiving And Processing Module 1 Facility Final Safety Analysis Report, HNF-SD-W026-SAR-002 Rev. 0H, Waste Management Federal Services of Hanford, Inc., Richland, Washington, September 1998.

Scherpelz, R. I., 1991, HUDU - The Hanford Unified Dose Utility Computer Code, PNL-7636, Pacific Northwest Laboratory, Richland, Washington, February 1991.

Stone, W.A., J.M. Thorp, O.P. Gifford, and D.J. Hoitink, 1993 Climatological Summary for the Hanford Area, BNWL-1605, Pacific Northwest Laboratory, Richland, Washington. 